\title{
Late Cenozoic Tectonic Uplift Producing Mountain Building in Comparison with Mantle Structure in the Alpine-Himalayan
} Belt

\author{
Vladimir G. Trifonov*, Sergey Yu. Sokolov \\ Geological Institute of the Russian Academy of Sciences, Moscow, Russia \\ Email: ${ }^{*}$ trifonov@ginras.ru, ${ }^{*}$ vgtrifonov@yandex.ru, sysokolov@yandex.ru
}

Received 26 February 2014; revised 25 March 2014; accepted 12 April 2014

Copyright (C) 2014 by authors and Scientific Research Publishing Inc.

This work is licensed under the Creative Commons Attribution International License (CC BY). http://creativecommons.org/licenses/by/4.0/

(c) ()) Open Access

\section{Abstract}

Tectonic uplift producing recent mountain systems has spanned in the Alpine-Himalayan Belt the time interval from Oligocene to Recent (the last 30 - 35 Ma), being divided into two stages. During the first stage, local uplands, usually not higher than middle-elevated mountains, rose and their total area increased. During the second stage (the last 5 - $2 \mathrm{Ma}$ ) this process was accompanied by a total uplift of the greater part of the belt. As a result, the rate of vertical movements increased, the recent mountain systems were formed, and the coarse molasses accumulated in the adjacent basins. Uplift of the land surface resulting in formation of mountain topography is an isostatic reaction to decompaction of the upper spheres of the Solid Earth. Three factors of the decompaction are discussed in the paper. These are: I, collisional compression, resulting in deformational thickening of the Earth's crust (folding, thrusting, etc.); II, partial replacing of the lithosphere mantle by the lower-dense asthenosphere material and, as a result, decompaction of the uppermost mantle; and III, retrograde metamorphism of high-metamorphosed rocks within the lower crust and near the crust-mantle boundary and, as a result, decompaction of these rocks. These processes were initiated or facilitated by the lateral asthenosphere flows. According to the seismic tomography data, the flows spread from the stationary developed zone of the rise of deep mantle material that is expressed in the recent structure as the Ethiopian-Afar super-plume. Reworking the 400 $700-\mathrm{km}$ deep transition layer of the mantle, the sub-lithosphere flows could be enriched in sources of aqueous fluids. The flows and their fluids initiated factors II and III of the tectonic uplift and caused softening and detachment of the lithosphere, facilitating deformational thickening of the Earth's crust, i.e., the factor I. The latter produced uplands during the entire Oligocene-Quaternary development of the orogenic belt, while the factors II and III manifested themselves only during the second stage of mountain building. The detailed studies in the Central Tien Shan and 
the Greater Caucasus showed that the acceleration of uplift at the second stage was caused mainly by the factor II in the Central Tien Shan and the factor III in the Greater Caucasus.

\title{
Keywords
}

\author{
Late Cenozoic Uplift, Mountain Building, Seismic Tomography Profiles, Lithosphere, \\ Asthenosphere
}

\section{Introduction}

Uplift of land surface producing mountain building is an isostatic result of decompaction (decrease of density) of the upper spheres of the Solid Earth in the lithosphere level. Three factors of the decompaction are discussed below. They are: I, lateral compression, resulting in deformational thickening of the Earth's crust (folding, flattening, thrusting, etc.); II, partial replacing of the lithosphere mantle by the lesser-dense asthenosphere material; III, partial decompaction of some volumes within the crust and near the crust-mantle boundary because of the retrograde metamorphism of the high-metamorphosed rocks.

To estimate a role of the factor I, we used the equations [1]:

$$
\begin{aligned}
\Delta h_{\mathrm{c}} & =h_{1}-h_{0}=\left[\left(L_{0}-L_{1}\right) / L_{1}\right] h_{0} ; \\
H_{\mathrm{c}} & =\left[\left(\rho_{\mathrm{m}}-\rho_{\mathrm{c}}\right) / \rho_{\mathrm{m}}\right] \Delta h_{\mathrm{c}},
\end{aligned}
$$

where $H_{\mathrm{c}}$ is crustal uplift under local isostasy (m), $\Delta h_{\mathrm{c}}$ is thickening of the crust (m), $L_{0}, L_{1}, h_{0}, h_{1}$ are the initial and final values, correspondingly, of the width of the compressed area and the thickness of its crust $(\mathrm{km}), \rho_{\mathrm{m}}$ is density of the most upper mantle $\left(\mathrm{kg} / \mathrm{m}^{3}\right)$, and $\rho_{\mathrm{c}}$ is the average density of the continental crust $\left(\mathrm{kg} / \mathrm{m}^{3}\right)$. Many researchers consider this factor to be the single or, at least, main source of the Late Cenozoic tectonic uplift. During the last years, the authors of the present paper published several papers, where they argued the significant and leading in many areas role of the factors II and III in this uplift [2]-[6]. The present paper is the synthesis of the data on history, mechanisms and sources of the Late Cenozoic (Oligocene-Quaternary, i.e., the last 30 - $35 \mathrm{Ma}$ ) uplift producing mountain building in the central Alpine-Himalayan Orogenic Belt from the Eastern Alps and Dinarides-Hellenides up to the Himalayas and Central Asia (Figure 1). Because detailed evidence of the data under discussion has been published in our previous papers, we do not represent here this evidence, referring to the corresponding publications.

\section{Neotectonic Data}

\subsection{Pre-History}

The mountain systems of the central Alpine-Himalayan Belt inherit structures related to evolution of the Tethys Ocean. The longitudinal zoning of the belt, with the continental crust becoming younger toward the south, is determined by the Tethys geodynamics. Its south-western margin was passive, whereas its north-eastern margin was active. On the passive margin, rifting, which transformed into spreading, separated Gondwana fragments and they moved to the north-east. Here the Tethyan oceanic lithosphere subducted beneath the margins of the northern plates. The successive formation of the Paleo-, Meso-, and Neo-Tethys led to the accretion of new Gondwana fragments to the northern plates; the fragments were separated by sutures, accretionary wedges, and magmatic manifestations of the corresponding stages of Tethyan evolution. This process began with the breakup of Pangea and became well-defined in the Mesozoic and Cenozoic, when the northern plates merged into the Eurasian Plate.

The mountain systems of the belt inherit mainly the northern active margin of the Neo-Tethys, whereas its southern passive margin is host to few mountain systems, the largest being the Himalayas and the Zagros. The mountains of the northern edge of the belt (the Greater Caucasus, the Kopet Dagh, the Tien Shan, the northern Afghanistan, the northern Pamirs, the Kunlun, and the northern Tibet) formed on the Paleozoides, whose portion in the orogenic belt decreased to the west. Farther south, there are sutures and other structural indicators of dif- 


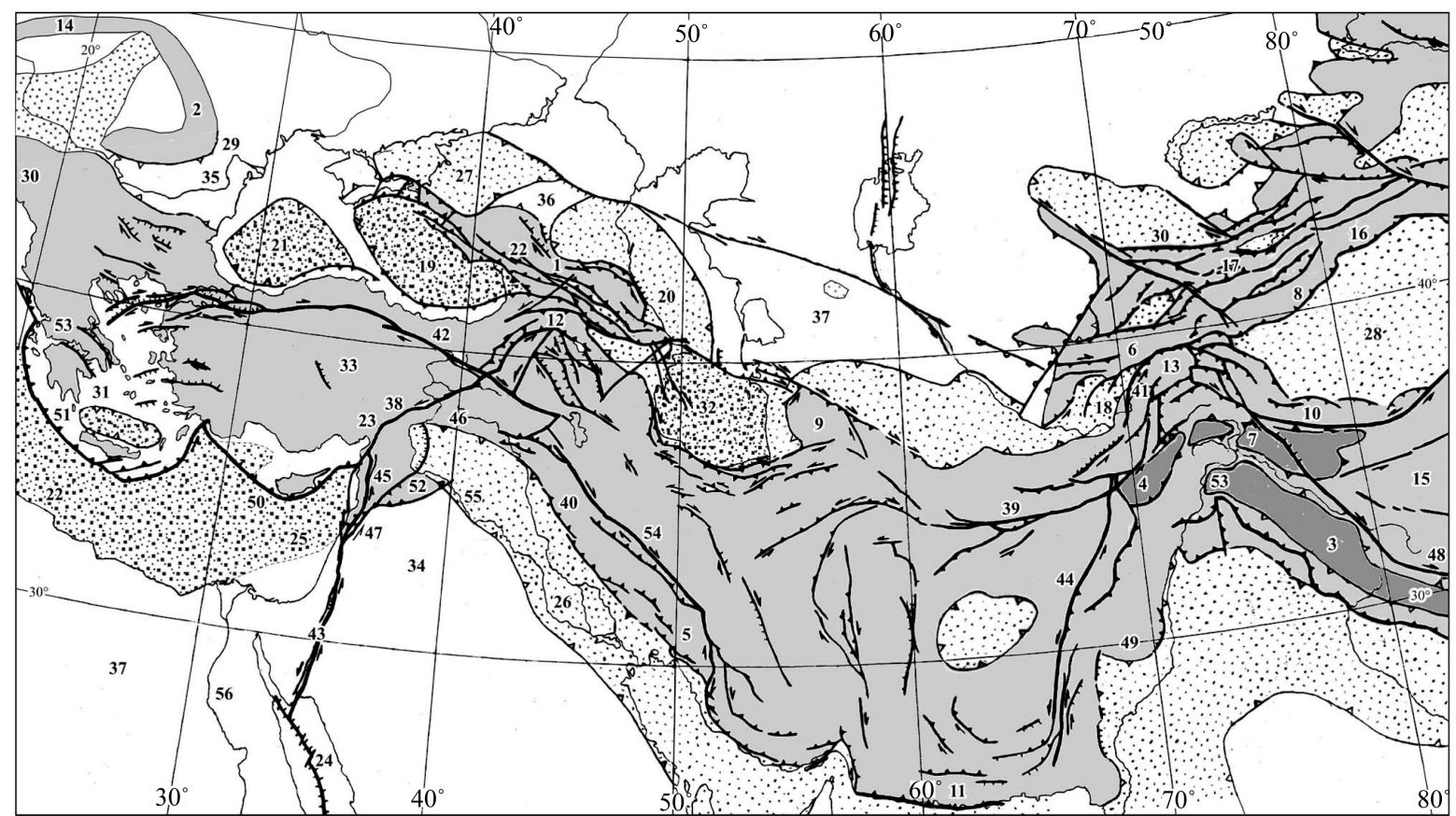

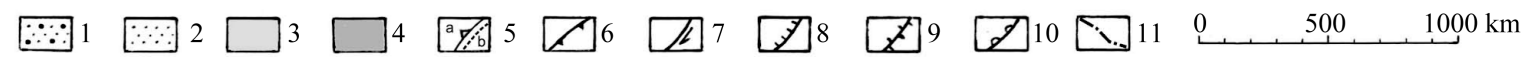

Figure 1. Pliocene-Quaternary structure of the Alpine-Himalayan Belt from Eastern Mediterranean to Central Asia. 1, basins with sub-oceanic crust; 2, major basins on continental crust; 3, mountains (in Figure 1) and uplands not higher than $1.5 \mathrm{~km}$ (in Figure 6); 4, highest mountains; 5, boundaries of mountains and basins: (a) in Figure 1 and (b) in Figure 6; 6 - 10, faults (the largest faults are shown by thickened lines in Figure 1): 6, thrust or reverse fault, 7, strike-slip fault, 8, normal fault, 9, extension fault, 10, flexure; 11, the Tesseire-Tornquist and Palmyra-Apsheron lineaments (in Figure 6). Mountains: (1) Greater Caucasus, (2) Eastern Carpathians, (3) the Himalayas, (4) Hindu Kush, (5) Zagros, (6) Western Tien Shan, (7) Karakoram, (8) Kokshaal, (9) Kopet Dagh, (10) Kunlun, (11) Makran, (12) Lesser Caucasus, (13) Pamirs, (14) Northern Carpathians, (15) Tibet, (16) Khan Tengri, (17) Central and Eastern Tien Shan, (22) Elbrus, (30) Dinarides, (45) Coastal Range (in Syria), (47) Lebanon Range; basins: (18) Afghan-Tadjik, (19) Eastern Black Sea, (20) Terek-Derbent, (21) Western Black Sea, (23) Misis-Andirin (paleo-basin), (24) Red Sea (rift), (25) Levantine, (26) Mesopotamian, (27) Azov-Kuban, (28) Tarim (microplate), (29) Focsani (a part of the Carpathian Foredeep), (31) Aegean, (32) South Caspian; platforms: (33) Anatolian, (34) Arabian, (35) Moesian, (36) Scythian, (37) African; faults and fault zones: (38) East-Anatolian Zone, (39) Herat, (40) Main Recent Fault of Zagros, (41) Darvaz, (42) North-Anatolian Zone, (43) Dead Sea Transform, (44) Chaman, (46) South Taurus; tectonic zones: (48) Indus-Tsang Po, (49) Quetta, (50) Cyprus Arc, (51) Crete-Hellen Arc, (52) Palmyrides, (53) Hellenides, (54) Sanandaj-Sirjan; rivers: (55) Euphrates, (56) Nile.

ferent stages of the Meso-Tethys; and still farther south there are those of the Neo-Tethys [7]-[10]. The active margin was complicated by back-arc basins with a thin sub-oceanic crust, which closed simultaneously with the Tethys or later. Relics of the subducted oceanic and sub-oceanic crust are preserved in the form of high-velocity matter at different lithosphere levels and are expressed by igneous xenoliths.

From the Late Paleozoic till the Paleogene, the Tethys was a bay of the Pacific narrowing to the north-west and linear rates of horizontal movements decreased to the west as a whole at different stages of its development and closure. This trend continued after beginning of collision in the Cenozoic. This is expressed both in different magnitudes of strike slip in similar local structures (for example, on the western flank of the Indian Plate as compared with the Arabian Plate) and in different transverse shortening of the belt segments [7] [8] [11].

In the Eocene, the vast eastern portions of the future mountain belt were flat or hilly lowlands, whereas the rest of the territories, mainly in the west, were covered by shallow epi-continental seas. Thin-crust (sub-oceanic) basins stood out this background and represented relics of the Tethys itself and its back-arc basins [12]-[15] (Figure 2). The Tethyan relics existed in the Trans-Himalayas (Indus-Tsang Po Zone), southwards of the Makran (this basin would later become the periphery of the Indian Ocean), between the future Arabian Plate and the Sanandaj-Sirjan Zone of Iran, and in front of the north-western Arabian Plate. Among the back-arc basins, the near W-E-trending Carpathian-Greater Caucasus system of troughs was the largest. It extended from the Outer 


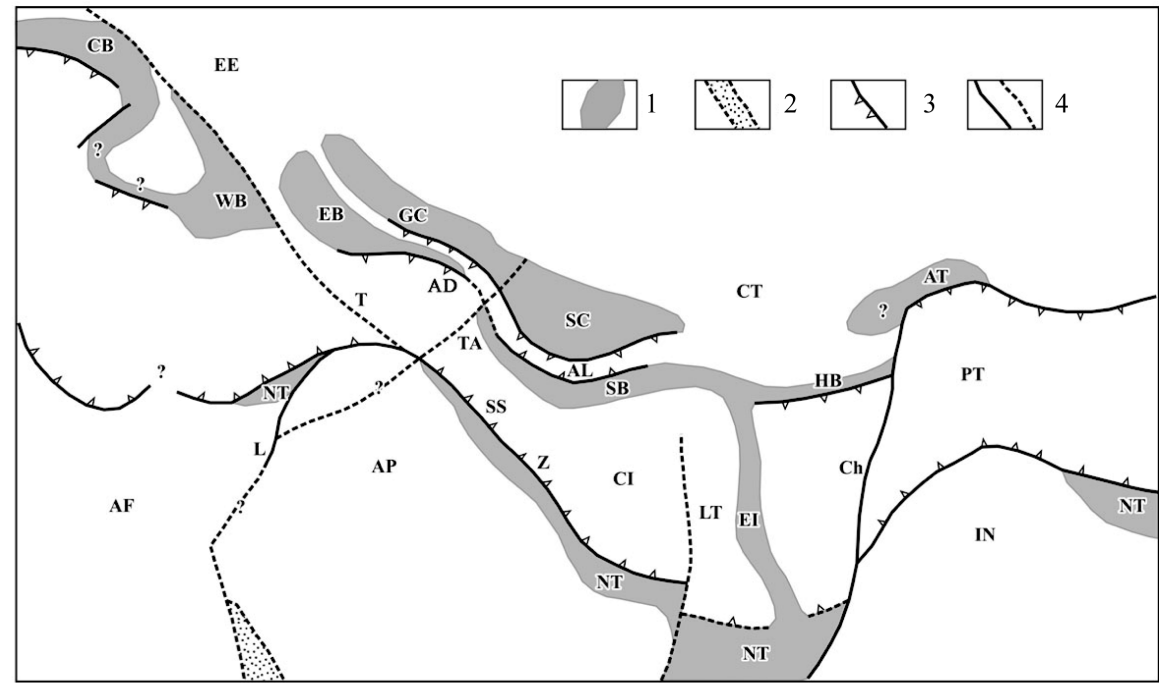

Figure 2. Conceptual map of the basins with a thin (suboceanic) crust in the Alpine-Himalayan Belt in the Eocene ( 45 Ma ago), modified after [5] [6] [12]-[15]. 1, thin-crust basins; 2, Red Sea proto-rift basin; 3, major thrusts and subduction zones; 4, major transform and other faults and their supposed continuations. AD, Adjaro-Trialetia; AF, African Plate; AL, Alborz; AP, Arabian Plate; AT, Afghan-Tadjik Basin; CB, Carpathian Basin; Ch, proto-Chaman Transform; CI, Central Iran Microplate; EB, Eastern Black Sea Basin; EE, East European Platform; EI, East Iranian Basin; GC, Greater Caucasus Basin; HR, Hari-Rud Basin; IN, Indian Plate; L, proto-Levant Transform; LT, Lut Microplate; NT, Neo-Tethys relics; PT, Pamirs, Tibet; SB, Sabzevar Basin; SC, South Caspian Basin; SS, Sanandaj-Sirjan zone; T, proto-North Anatolian Fault, extending into the PechenegaKamena Fault and the Tesseire-Tornquist Line; TA, Talysh; WB, Western Black Sea Basin; Z, Main Zagros Thrust.

Carpathian Zone up to the proto-South Caspian Basin. The troughs were separated by the NW-trending relative uplifts, being partly areas of shallow-water sedimentation. To the south of this system, the Sabzevar trough reached Talysh in the west, extended to the east as the Hari-Rud Basin, and was linked with the Makran Tethyan relic via the East Iranian Basin. The sub-oceanic basins were shorted by the folding, which began at the late Middle Eocene.

The further Late Cenozoic uplift producing mountain systems developed in two stages: 1 ) from the Oligocene until the Early Pliocene, and 2) during the last $\sim 5$ - 2 Ma (perhaps, from the Late Miocene in some regions). The history of the uplift is analyzed lower in the examples of the Central Tien Shan and the Greater Caucasus.

\subsection{The Central Tien Shan}

The Central Tien Shan (CTS) is a part of the Tien Shan Mts. between the epi-Paleozoic Kazakh Shield in the north, the Tarim microplate in the south, the Talas-Fergana Fault in the west, and the Eastern (Chinese) Tien Shan in the east (Figure 3). The CTS formed on the epi-Paleozoic continental crust, which was similar initially with the $42-\mathrm{km}$ thick recent crust of portions of the Kazakh Shield, non-deformed in the Late Cenozoic [16]. The Cenozoic evolution of the CTS is described, using the data from [4] [17]-[21].

At the Paleocene and Eocene, the CTS area was a peneplain with mutual uplifts reaching few hundreds of meters, which was considered a pre-orogenic planed surface. Resedimented crust of weathering forms the thin clastic unit with fossils of the Middle-Upper Eocene and perhaps the Lower Oligocene. Its lower part includes basalts with the K-Ar and Ar-Ar dates of 54 - 70 Ma [22]-[24].

The Oligocene is represented by conglomerates (mostly fine-pebble) and finer clastic deposits. The domestic clastic material is present and often dominates in pebbles [25]. This proves that basic structures of recent topography were originated just at that time. They were the ENE-trending still low, according to the data on magnitudes of incision, uplands (areas of denudation) and basins (areas of sedimentation). Intensity of vertical move- 


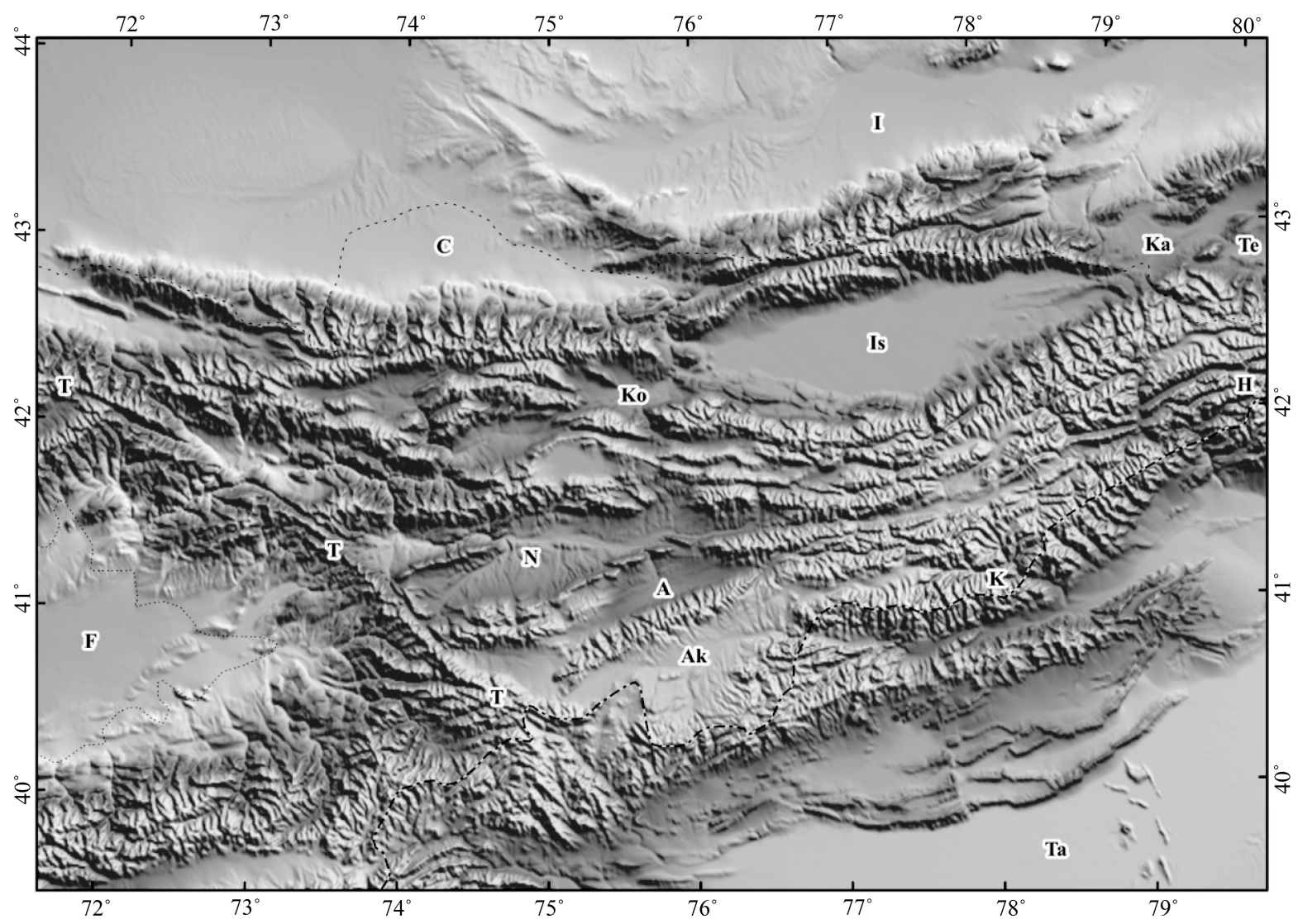

Figure 3. The Cenrtal Tien Shan. A, Atbashi Basin; Ak, Aksai Basin; C, Chu Basin; F, Fergana Basin; H, Khan Tengri; I, Ili Basin; Is, Issyk-Köl Basin; Ka, Karkara Basin; Ko, Kochkor Basin; K, Kokshaal; N, Naryn Basin; T, Talas-Fergana Fault; Ta, Tarim Basin; Te, Tekes Basin. The China-Kyrghyzstan boundary is shown.

ments and incision decreased in the Miocene (Table 1 and Figure 4). The fine-grained lake deposits (with evaporates in some areas) dominate, whereas the alluvium is relatively rare [25]. Areas of sedimentation expanded into a part of the Oligocene uplands. To the south and east, towards the highest recent mountains - the Kokshaal Ridge and Khan Tengri, the clastic material becomes coarser that indicates the higher elevation and erosion. In the Late Miocene, the incision on mountain slopes and basin sedimentation accelerated and content of coarse-grained material increased in the sediments, but they became finer-grained again in the Pliocene (Table 1 and Figure 4). The average height of the CTS did not probably exceed $\sim 1 \mathrm{~km}$ in the end of the Pliocene and it could be more only in the Khan Tengri area. If the average altitude of the pre-orogenic peneplain was $\sim 0.3 \mathrm{~km}$, the magnitudes of uplift reached $\sim 0.7$ - $1 \mathrm{~km}$ during the stage 1 (Oligocene to Pliocene).

Using the data from [4] [26] [27], we estimated the total Oligocene-Quaternary transverse shortening of the CTS as $50-70 \mathrm{~km}$. So, the average rate of the shortening is $\sim 2 \mathrm{~mm} / \mathrm{a}$ (mm per year), and the initial width of the CTS $\left(L_{0}\right)$ was $450-470 \mathrm{~km}$. Substituting these values to Equations (1) and (2), we receive $\Delta h_{\mathrm{c}}=4-6 \mathrm{~km}$ and $\mathrm{H}_{\mathrm{c}}$ $=0.6-0.9 \mathrm{~km}$ for the stage $1 . \mathrm{H}_{\mathrm{c}}$ coincides approximately with the geological estimate of uplift. This proves that compression was the main source of uplift during the stage 1.

During the stage 2 (the last $~ 2 \mathrm{Ma}$ ), a quick rise of the CTS mountains took place, including some portions of intermountain basins and the foredeep. This is proved by high magnitudes of incision in mountain slopes (Figure 4) and accumulation of coarse molasses in basins. The average altitude of the CTS reached $\sim 3 \mathrm{~km}$ and some mountains rose up to $6-7 \mathrm{~km}$ in the south-east. According to the GPS data, the rate of transverse shortening is $10-13 \mathrm{~mm} / \mathrm{a}$ in the Kyrghys part of the CTS [28] [29] and 20 mm/a in the CTS as a whole [30] [31]. The rate of shortening, calculated by summing seismic moments of the XX century earthquakes is $7 \pm 2 \mathrm{~mm} / \mathrm{a}$ [32]. The rate of shortening, calculated by summing offsets on active faults of the Kyrghys CTS is $\sim 10 \mathrm{~mm} / \mathrm{a}$ [33] or $\geq 5 \mathrm{~mm} / \mathrm{a}$ [34]. If we take the average rate of shortening of $\sim 10 \mathrm{~mm} / \mathrm{a}$ for the stage 2 and use Equations 
Table 1. Thicknesses and rates of accumulation of the Paleogene-Lower Quaternary molasse complexes in the Central Tien Shan, data from [4] [17] [18] [20] [23].

\begin{tabular}{|c|c|c|c|c|c|c|c|c|c|c|c|c|c|}
\hline \multirow{3}{*}{ อั๋ } & \multirow{3}{*}{ 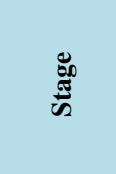 } & \multirow{3}{*}{ 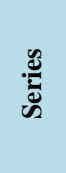 } & \multirow{3}{*}{ 苞 } & \multirow{3}{*}{ 总 } & \multicolumn{9}{|c|}{ Basin } \\
\hline & & & & & Chu (south) & Kochkor & Issyk-Kul & Tekes & Karkara & Ili & Naryn & Atbashi & Aksai \\
\hline & & & & & \multicolumn{9}{|c|}{ Thickness, m/Rate, mm/year } \\
\hline Sh & & Sh & 12 & $\underline{0.8}$ & $\underline{1000-1300}$ & $\underline{200}$ & $\underline{500}$ & $\underline{250}$ & $\underline{350}$ & $\geq 20$ & $\underline{300}$ & $\geq 300$ & $\underline{300}$ \\
\hline SII & $\mathrm{Q}_{1}$ & Sn & 1.2 & $\overline{2}$ & $0.8-1.08$ & 0.167 & $0 . \overline{417}$ & $0 . \overline{208}$ & $\overline{0.28}$ & $>\overline{0.017}$ & $\overline{0.25}$ & $\overline{>0.25}$ & $\overline{0.25}$ \\
\hline \multirow{3}{*}{ 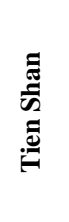 } & & & & 2 & $1250-1700$ & $\underline{200-850}$ & 1450 & 650 & 600 & $\underline{380-880}$ & 1200 & 650 & 1000 \\
\hline & $\mathrm{N}_{2}^{2}$ & $\mathrm{ts}_{2}$ & 3 & $\overline{5}$ & $0.4-0.57$ & $\begin{array}{c}0.067- \\
0.283\end{array}$ & 0.483 & 0.217 & 0.2 & $\begin{array}{c}0.127- \\
0.293\end{array}$ & 0.4 & 0.217 & 0.333 \\
\hline & $\mathrm{N}_{1}^{3}-\mathrm{N}_{2}^{1}$ & $\mathrm{ts}_{1}$ & 7 & $\underline{5}$ & $\underline{950}$ & $\begin{array}{c}\frac{150-1000}{0.0214-} \\
0.143\end{array}$ & $\frac{1380}{0.197}$ & $\frac{1400}{0.2}$ & 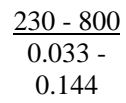 & 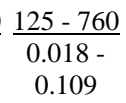 & $\frac{2000}{0.286}$ & $\frac{2500}{0.357}$ & $\frac{1200}{0.171}$ \\
\hline \multirow{2}{*}{$\frac{5}{5}$} & $\mathrm{~N}_{1}^{1}-\mathrm{N}_{1}^{2}$ & $\mathrm{kz}_{2}$ & 10 & $\frac{12}{22}$ & $\frac{150-600}{0.015-0.06}$ & $\frac{450-1700}{0.045-0.17}$ & $\frac{800}{0.08}$ & $\begin{array}{c}\frac{170-500}{0.017-} \\
0.05\end{array}$ & $\frac{150-700}{0.015-}$ & $\begin{array}{c}\frac{160-670}{0.016-} \\
0.067\end{array}$ & $\begin{array}{c}\frac{670-}{1000} \\
0.067- \\
0.1\end{array}$ & $\begin{array}{c}\frac{450-}{1000} \\
0.045- \\
0.1\end{array}$ & $\frac{450}{0.045}$ \\
\hline & $\begin{array}{l}\mathrm{E}_{3}\left(\mathrm{E}_{3}^{2-3}\right) \\
-\mathrm{N}_{1}^{1} a\end{array}$ & $\mathrm{kz}_{1}$ & 8 & $\frac{22}{30}$ & $\frac{150-600}{0.019-}$ & 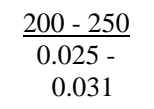 & $\begin{array}{c}\frac{500-600}{0.063-} \\
0.075\end{array}$ & No data & $\frac{200}{0.025}$ & $\frac{390}{0.049}$ & $\frac{500}{0.063}$ & $\frac{600}{0.075}$ & $\frac{100-450}{0.012-}$ \\
\hline 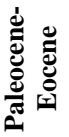 & $\begin{array}{l}E_{1-2}- \\
\left(E_{3}^{1}\right)\end{array}$ & $\mathrm{E}$ & 36 & $\frac{30}{60}$ & $\frac{150-635}{0.0041-}$ & $\frac{\underline{7}}{0.0002}$ & $\begin{array}{c}\frac{100-550}{0.0028-} \\
0.0153\end{array}$ & No data & No data & 0.0089 & $\frac{100}{0.0022}$ & $\frac{80}{0.0022}$ & $\begin{array}{c}\frac{10-350}{0.0003-} \\
0.0098\end{array}$ \\
\hline
\end{tabular}

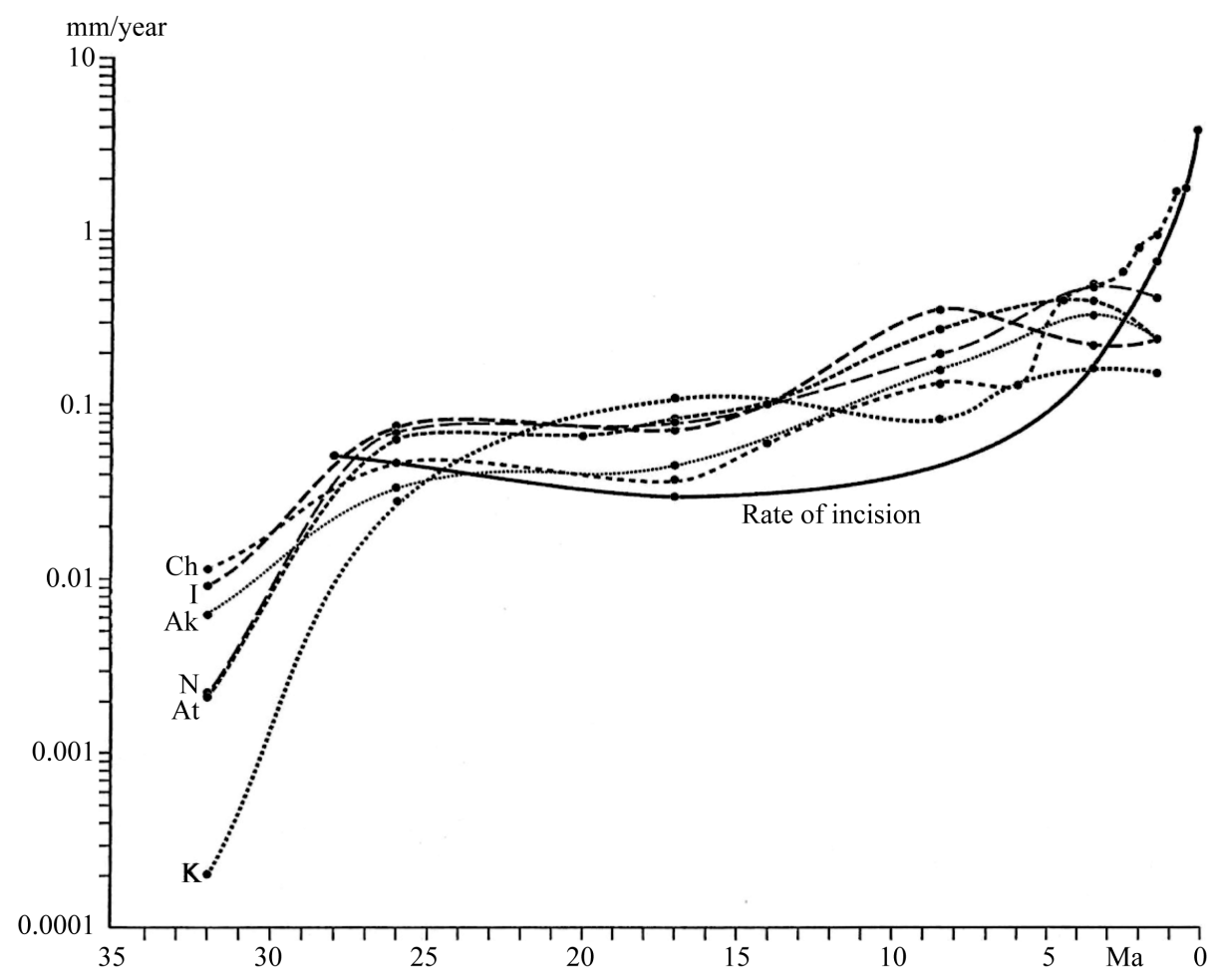

Figure 4. Changes of the rates of sedimentation in the Cenozoic basins and in rates of incision of drainage systems into ridges of the Central Tien Shan. Deceleration of deposit accumulation in the Aksai, Kochkor, Naryn basins in the Quaternary was caused by the transition from basin sedimentation to terrace regime. Basins: Ak, Aksai; At, Atbashi; Ch, Chu; I, Issyk-Köl; K, Kochkor; N, Naryn. 
(1) and (2), $\Delta h_{\mathrm{c}}=2.3-2.4 \mathrm{~km}$ and $\mathrm{H}_{\mathrm{c}}=0.35-0.36 \mathrm{~km}$. This is less than $20 \%$ of the total uplift of the CTS during the stage 2 .

\subsection{Greater Caucasus}

To understand sources of uplift of the Greater Caucasus (GC), we estimated consequently the following characteristics: 1) thickness and composition of the Earth's crust before its compressional deformation; 2) values of transverse shortening, thickening and uplift of the crust because of the compression; 3) transformation of the deformed crust into the recent mountain system. The used data on the Mesozoic-Cenozoic geology of the GC are based on the publications [14] [35]-[38]. The main part of the GC formed in the margin of the epi-Paleozoic Scythian Plate. Its part, weakly deformed in Mesozoic and Cenozoic is separated from the GC by the foredeeps, Azov-Kuban in the west and Terek-Derbent in the east (Figure 5). The transitional Laba-Malka Zone (LMZ), including the East Balkar sub-zone and Limestone Daghestan, extends along the northern slope of the GC [14]. The thickness of the LMZ sedimentary cover varies from 5 - $5.5 \mathrm{~km}$ in the central part to 6.5 - $7 \mathrm{~km}$ in the east and $\sim 10 \mathrm{~km}$ in the north-west. The GC itself consists of the north-western, central and eastern segments. The North-Western Caucasus is composed of the Jurassic, Cretaceous, and Paleogene (in the peripheral parts) deposits; their total thickness is up to $14 \mathrm{~km}$. The same deposits were $\sim 11 \mathrm{~km}$ thick in the Eastern Caucasus in the Early Miocene, although that region was subjected to the Cimmerian (pre-Bathonian and pre-Callovian) folding. In the Central Caucasus, the Lower and Middle Jurassic deposits were intensively deformed by the Cimmerian folding and preserved only in compressed synclines between the Paleozoic blocks. Upper Jurassic to Paleogene deposits covered this uplift of the basement. We estimated their total thickness in the Early Miocene as $~ 2-2.5$ $\mathrm{km}$. The southern part of the GC (Zone of Southern Slope, ZSS) is separated from the GC itself by the Main

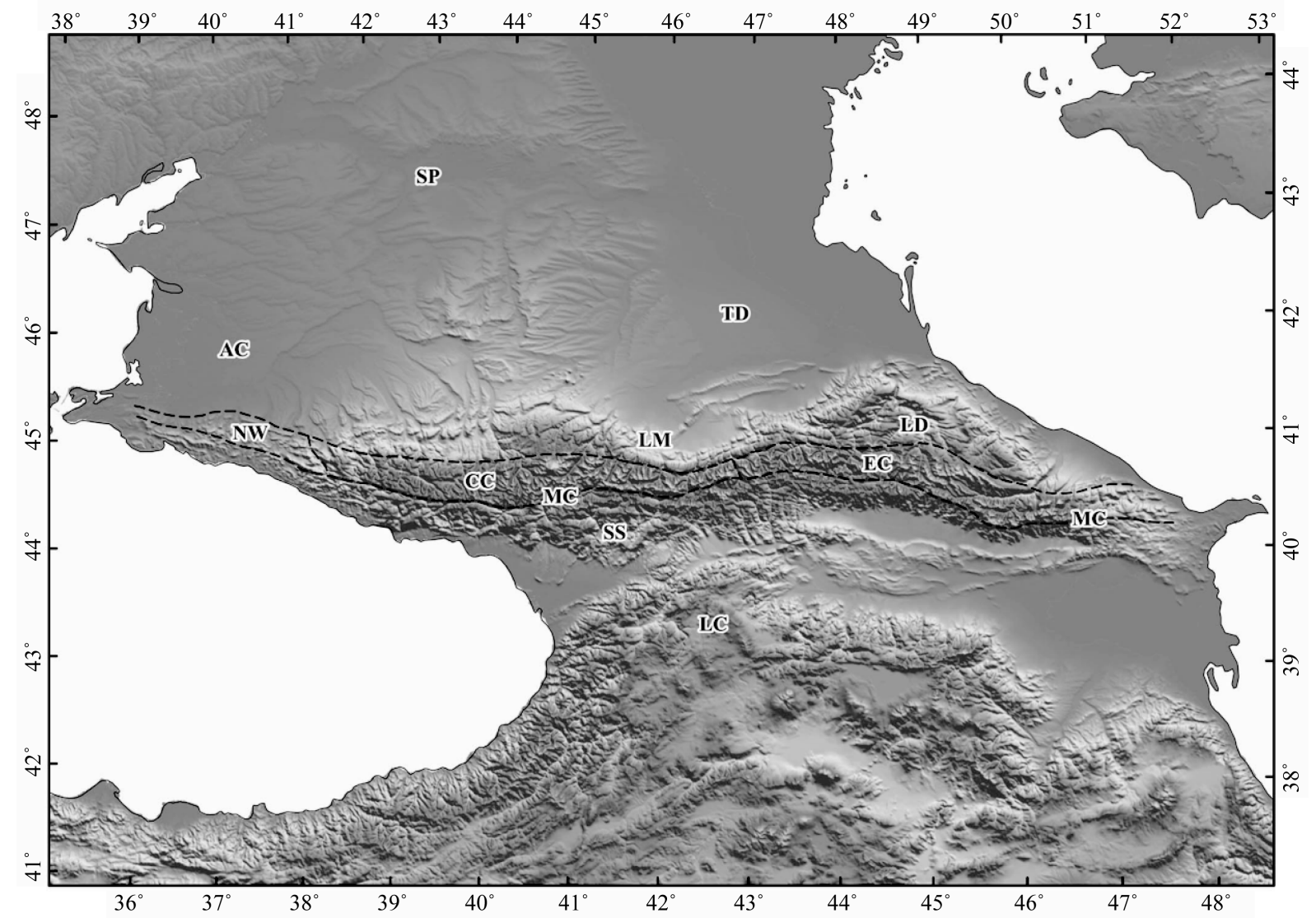

Figure 5. Greater Caucasus. AC, Azov-Kuban Basin; CC, Central Caucasus; EC, Eastern Caucasus; LC, Lesser Caucasus; LD, Limestone Daghestan; LM, Laba-Malka Zone; MC, Main Caucasus Fault; NW, North-western Caucasus; SP, Scythian Platform; SS, Southern Slope Zone; TD, Terek-Derbent Basin. 
Caucasus Reverse Fault. Near this fault, the ZSS is composed of the Lower and Middle Jurassic deposits, which are overlaid with the Upper Jurassic to Paleogene mainly flysch deposits farther to the south. Both parts of the ZSS represented a single basin with the 15 - 20-km total thickness of the sediments in the Early Miocene. Reconstructing the Earth's crust structure of different zones of the GC in the Early Miocene (Table 2), we considered that the crust was in isostatic balance at that time and the land surface differed from the sea level not more than to $\sim 300 \mathrm{~m}$. We estimated the average density of the sedimentary cover as $2.5 \mathrm{~g} / \mathrm{cm}^{3}$ and considered that the density of the basement beneath thick sedimentary basins increased up to $2.9-2.93 \mathrm{~g} / \mathrm{cm}^{3}$, by analogy with other similar structures [1].

The Mesozoic and Cenozoic deposits of the GC are deformed by folds and faults. We analyzed deformation that was due to compression and resulted in transverse shortening of the Earth's crust. Using the published data [14] [26] [38]-[42], supplemented by our calculation of shortening in the LMZ and Limestone Daghestan, we estimated the transverse shortening and, correspondingly, the deformational uplift of the land surface in different zones by Equations (1) and (2) (Table 3).

The age of main phase of the Late Alpine deformation is under discussion. We consider it to be post-Maykopian, i.e., late Early and Middle Miocene, because the Maikopian (Oligocene-Lower Miocene) marine deposits covered the Greater Caucasus and the Maikopian Basin inherited the previous sedimentation in the region [37] [43]. But the actual situation is more complicated. In the Central Caucasus, the significant deformation occurred at the pre-Bathonian and pre-Callovian time. As a result, the area became the uplifted block of the consolidated crust. Thickening and isostatic uplift of the Central Caucasus crust explain erosion of the Lower and Middle Jurassic deposits and exhumation of the Paleozoic basement. However, the Cimmerian deformation in the Eastern Caucasus did not produce significant pre-Late Jurassic uplift and erosion. The Moho is characterized there by the boundary velocities $V_{P}=8.2-8.3 \mathrm{~km} / \mathrm{s}$. The seismic profiling found the layer with the velocities decreased up to $7.8 \mathrm{~km} / \mathrm{s}$ under the Moho at the depths of $59-66 \mathrm{~km}$ and the discontinuity with boundary velocity $V_{P}=8.5$ $\mathrm{km} / \mathrm{s}$ under it [44]. Perhaps, this lower discontinuity is a relic of the former bottom of the crust. Its lower layers were subjected to metamorphism and their density came nearer to the mantle one. The densification com-

Table 2. Calculated characteristics of the Earth's crust of Greater Caucasus in the Early Miocene.

\begin{tabular}{ccccc}
\hline Tectonic zone & Thickness of J-Pg cover & Thickness of basement & Density of basement & Thickness of the crus \\
\hline Zone of the Southern Slope & $18 \pm 2 \mathrm{~km}$ & $\sim 16 \pm 1 \mathrm{~km}$ & $2.93 \mathrm{~g} / \mathrm{cm}^{3}$ & $\sim 34 \pm 2 \mathrm{~km}$ \\
North-Western Caucasus & $\sim 14 \mathrm{~km}$ & $\sim 21 \mathrm{~km}$ & $2.9 \mathrm{~g} / \mathrm{cm}^{3}$ & $\sim 35 \mathrm{~km}$ \\
Central Caucasus & $2-2.5 \mathrm{~km}$ ? & $\sim 40 \mathrm{~km}$ & $2.83 \mathrm{~g} / \mathrm{cm}^{3}$ & $\sim 42 \mathrm{~km}$ \\
Eastern Caucasus & $\sim 11 \mathrm{~km}$ & $\sim 25 \mathrm{~km}$ & $2.87 \mathrm{~g} / \mathrm{cm}^{3}$ & $\sim 36 \mathrm{~km}$ \\
LMZ, western segment & $\sim 10 \mathrm{~km}$ & $\sim 26 \mathrm{~km}$ & $2.85 \mathrm{~g} / \mathrm{cm}^{3}$ & $\sim 36 \mathrm{~km}$ \\
LMZ, central segment & $\sim 5 \mathrm{~km}$ & $\sim 34 \mathrm{~km}$ & $2.84 \mathrm{~g} / \mathrm{cm}^{3}$ & $\sim 39 \mathrm{~km}$ \\
LMZ, eastern segment & $\sim 7 \mathrm{~km}$ & $\sim 31 \mathrm{~km}$ & $2.85 \mathrm{~g} / \mathrm{cm}^{3}$ & $\sim 38 \mathrm{~km}$ \\
\hline
\end{tabular}

LMZ is the Laba-Malka Zone.

Table 3. Calculated values of the fold thickening of the Earth's crust and related isostatic uplift of the land surface in the Greater Caucasus.

\begin{tabular}{|c|c|c|c|c|c|}
\hline Tectonic zone & $\begin{array}{l}\text { Initial thickness of } \\
\text { the crust, km }\end{array}$ & Shortening & $\begin{array}{l}\text { Post-folding thickness } \\
\text { of the crust, km }\end{array}$ & $\begin{array}{l}\text { Thickening of } \\
\text { the crust, km }\end{array}$ & Isostatic uplift, km \\
\hline ZSS & $\sim 34 \pm 2$ & $\sim 50 \%$ & $\sim 68 \pm 4$ & $\sim 34 \pm 2$ & $\sim 4.8-5.4$ \\
\hline North-western Caucasus & $\sim 35$ & $\sim 20 \%$ & $\sim 44$ & $\sim 9$ & $\sim 1.4$ \\
\hline Central Caucasus, Cimmerian & $\sim 38 ?$ & $20 \%-30 \% ?$ & $\sim 48-52 ?$ & $\sim 10-14 ?$ & $\sim 1.5-2.1 ?$ \\
\hline Central Caucasus, Late-Alpine & $\sim 42$ & $10 \%-20 \% ?$ & $\sim 47-52$ & $\sim 5 \sim 10 ?$ & $\sim 0.8-1.5 ?$ \\
\hline Eastern Caucasus, Cimmerian & $\sim 38$ & $20 \%-30 \%$ & $\sim 48-52$ & $\sim 10-14$ & $\sim 1.5-2.1$ \\
\hline Eastern Caucasus, Late-Alpine & $\sim 36$ & $10 \%-20 \%$ & $\sim 40-45$ & $\sim 4-9$ & $\sim 0.6-1.4$ \\
\hline Limestone Daghestan & $\sim 38$ & $10 \%-20 \%$ & $\sim 42-48$ & $\sim 4-10$ & $\sim 0.6-1.5$ \\
\hline LMZ, east and center & $\sim 36-39$ & $<10 \%$ & $\sim 39-43$ & $<3-4$ & $<0.4-0.6$ \\
\hline
\end{tabular}


pensated the thickening of the crust and the Cimmerian uplift was not significant. The calculated crust thickness after the Late Alpine deformation differ in majority of the GC zones from the recent thickness of the Earth's crust, as it is determined by seismic profiling [44] [45]. The ZSS demonstrates the highest difference. This abnormally high calculated crust thickness and uplift are not corroborated by geophysical, geomorphological and geological (composition of molasses) data. Perhaps, there, as in the eastern Caucasus at the Cimmerian epoch, the densification of the Lower crust compensated the deformational thickening of the crust.

During the main phase of the Late Alpine deformation and immediately after it, i.e., in the Middle and early Late Miocene, the fine-grained material dominated in the molasses. Probably, the altitudes of deformational uplands did not exceed mid-level mountains (up to $\sim 1.5 \mathrm{~km}$ ). This corresponds to calculated elevation, except the ZSS (Table 3). Essential portions of the pebbles arrived in molasses of the GC and its surrounding only at the end of Miocene and became abundant at the Pliocene [35] [37]. Designing the conditional pre-orogenic surface of planation, Milanovsky E.E. [46] estimated the magnitudes of Late Cenozoic rise in different zones of the GC (Table 4). Everywhere, except the North-Western Caucasus and ZSS, the recent altitudes are higher than the calculated deformational uplift. This means that the GC grew more intensively from the end of Miocene [46] or the beginning of Pliocene [47] than it was caused by the deformational thickening of the crust. The magnitudes of uplift reached 1.5 - $2 \mathrm{~km}$ in the Central and Eastern Caucasus. The additional uplift probably occurred also in the zones, where the difference between $\mathrm{H}_{\mathrm{F}}$ and $\mathrm{H}_{\mathrm{R}}$ is unessential. For example, the topographic reversal presupposes erosion of the deformational topography and, correspondingly, additional uplift in the North-Western Caucasus.

\subsection{General Regularities}

Two stages of tectonic uplift that have been demonstrated in the CTS and the GC, are differentiated in all studied territories of the Alpine-Himalayan Belt. The stage 1 includes three sub-stages that were characterized by different orientation of the maximum lateral compression. These are: the Oligocene and Early Miocene; the late Early and Middle Miocene; and the Late Miocene (and the Early Pliocene or the entire Pliocene in some areas).

The compression was directed to the NNW-SSE at the first sub-stage (Figure 6(a)). The sub-oceanic Sabzevar and Indus-Tsang Po basins were closed [15]. Intense compressive deformation occurred in the Herat zone of Afghanistan and the Quetta region [48], and in the north-western Pamirs-Hindu Kush, where the deformation resulted in squeezing of the South-West Pamir Block to the east and its thrust over the South-East Pamir Zone [10]. The Oligocene-Miocene conglomerates overlaid the deformed older deposits with unconformity in the Indus-Tsang Po zone [49] as well as around the Pamirs and Kunlun [29]. Differentiated vertical movements occupied the Tien Shan and reached the Gornyi Altai as the sections of the Chuya Basin demonstrate [50]. In southern front of the western Taurides, subduction was completed with their collision with the Arabian Plate and overlaying of the accretionary wedge by the Lower Miocene deposits [13]. The Cyprus Arc was renewed and deformation culminated in the north-western Arabian Plate at 17 Ma [51]. Deformation developed in the Balkans and the southern Arabian-Caucasus region up to the southern flanks of the Caucasus basins. The collision of the Adria, the eastern Alps and the Carpathians with Eurasia that started in the late Middle Eocene, lasted

Table 4. Correlation between the calculated values of the Earth's crust thickness before and after the main phase of the LateAlpine folding and post-folding uplift and the recent values of the crust thickness and uplift of the land surface.

\begin{tabular}{|c|c|c|c|c|c|c|c|c|}
\hline Zone & $h_{0}, \mathrm{~km}$ & $S_{0}, \mathrm{~km}$ & $h_{\mathrm{F}}, \mathrm{km}$ & $S_{\mathrm{F}}, \mathrm{km}$ & $\mathrm{H}_{\mathrm{F}}, \mathrm{km}$ & $h_{\mathrm{R}}, \mathrm{km}$ & $S_{\mathrm{R}}, \mathrm{km}$ & $\mathrm{H}_{\mathrm{R}}, \mathrm{km}$ \\
\hline ZSS & $32-36$ & $16-20$ & $64-72$ & $32-40$ & $4.8-5.4$ & $\begin{array}{c}35(\mathrm{~W})-45-50 \\
(\mathrm{C}-\mathrm{E})\end{array}$ & & $\begin{array}{l}\leq 1.5(\mathrm{~W}) \text { - up to } \\
2.5-3.5(\mathrm{C}-\mathrm{E})\end{array}$ \\
\hline NW Caucasus & $\sim 35$ & $\sim 14$ & $\sim 44$ & $\sim 17$ & $\sim 1.4$ & $\sim 41$ & & $1-1.5$ \\
\hline Central Caucasus & $\sim 42$ & $\sim 2.5(0-10)$ & $\sim 47-52$ & & $\sim 0.8-1.5 ?$ & $50-55$ & $\sim 2$ & $2.5-3.5$ \\
\hline Eastern Caucasus & $\sim 36$ & $\sim 11$ & $\sim 40-45$ & $\sim 13$ & $\sim 0.6-1.4$ & $54-55$ & $\sim 10$ & $\geq 3$ \\
\hline LMZ & $36-39$ & $5-10$ & $\sim 39-43$ & $\sim 6-11$ & $<0.4-0.6$ & $\sim 43$ & & $0.5-2$ \\
\hline LD & $\sim 38$ & $\sim 7$ & $\sim 42-48$ & & $\sim 0.6-1.5$ & $\sim 45$ & & $1-2$ \\
\hline
\end{tabular}

$h_{0}$ is the initial (before the Late-Alpine folding) thickness of the crust; $S_{0}$ is the initial thickness of the sedimentary cover; $h_{\mathrm{F}}$ is the post-folding thickness of the Earth's crust; $S_{\mathrm{F}}$ is the post-folding thickness of the sedimentary cover; $\mathrm{H}_{\mathrm{F}}$ is the post-folding uplift of the land surface; $h_{\mathrm{R}}$ is the recent position of the Moho surface (below s.l.); $S_{\mathrm{R}}$ is the recent thickness of the sedimentary cover; $\mathrm{H}_{\mathrm{R}}$ is the recent uplift of the land surface (above s.l.); LD, Limestone Daghestan. 

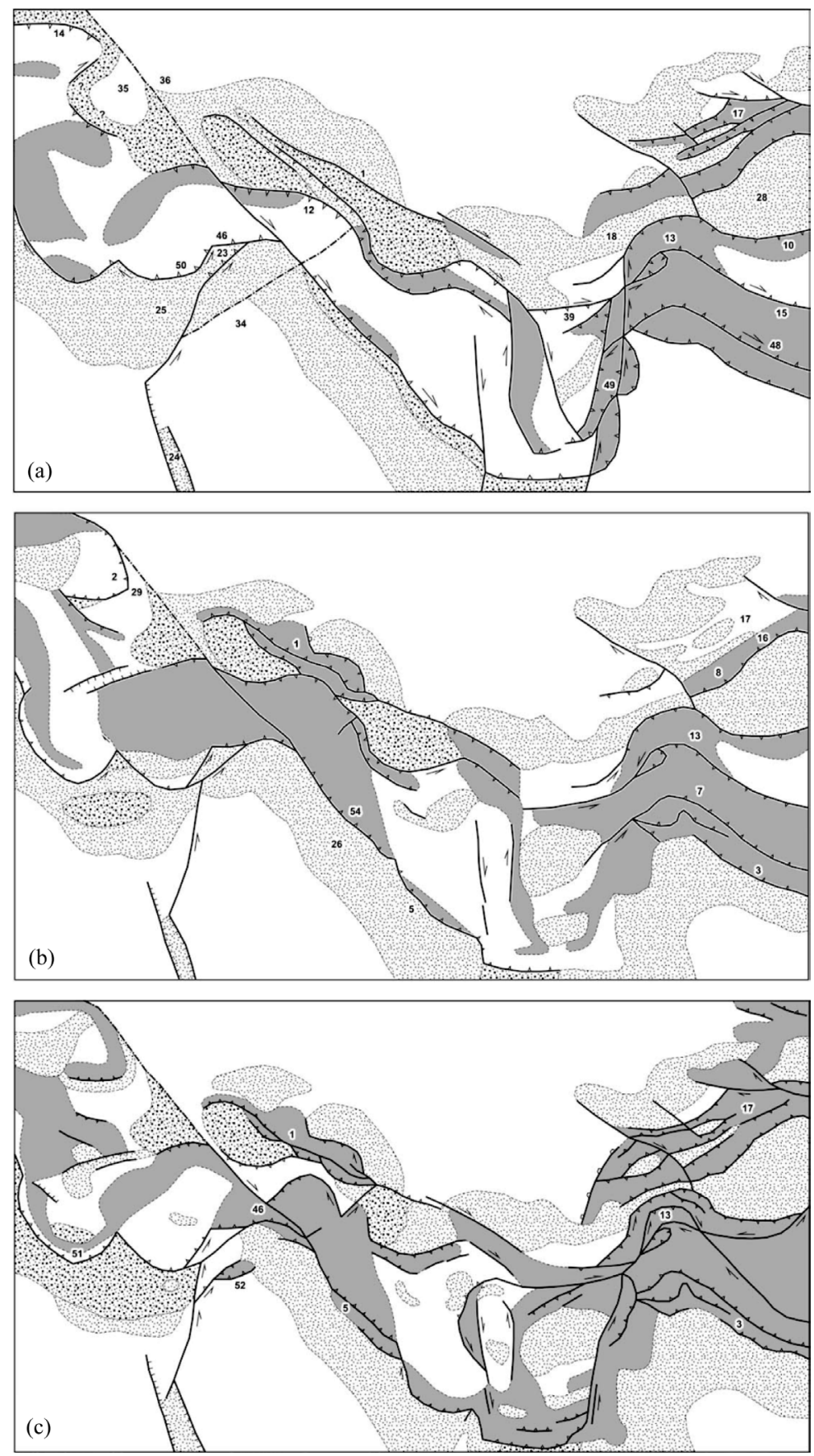

Figure 6. Conceptual maps of tectonic elements of the Alpine-Himalayan Belt at different sub-stages of stage 1: (a), the end of the Oligocene ( $25 \mathrm{Ma}$ ago); (b), the Middle Miocene ( 18 Ma ago); and the Messinian ( 6 Ma ago); modified after [6] [7] [10] [12]-[15] [25] [43] [52]-[55]. See Figure 1 for legend.

during the sub-stage 1 and was accompanied by the development of foredeep [12]. Offsets of the inner Carpathian zones gave birth to the Carpathian Arc. The deformation was completed at the late Early Miocene with thrust of the detached nappes of the northern Carpathians onto the foredeep. A graben of the future Aden-Red Sea Rift was originated in the Oligocene. This initiated beginning of a drift of the Arabia out of the African Plate and formation of the Dead Sea Transform at $\sim 20$ - 17 Ma ago. The northern part of the Transform extended along the continental slope of the Levantine Basin at that time [52]. 
The compression was directed to the NE-SW at the second sub-stage (Figure 6(b)). The Himalayas, the Karakoram and the NW-trending Pamir zones were involved in deformation and thrusting. At the same time, in the Central Tien Shan, where the Oligocene uplands struck to the ENE-WSW, vertical movements weakened and the areas of sedimentation expanded onto a part of the former uplands. The weakening of movements is registered also in the Chuya Basin of the Gornyi Altai [56]. The intense movements on the Main Thrust of Zagros resulted in closure of the Neo-Tethys relic between the Arabian Plate and the Sanandaj-Sirjan Zone [12].This initiated onset of the development of the Mesopotamian Foredeep, which inherited the formerly sagging margin of the Arabian Plate. Folding started at the north-eastern flank of the foredeep in the late MiddleLate Miocene [51]. The Caucasus basins of the Para-Tethys were closed and deformed [43] and the Outer zone of the eastern Carpathians was thrust over the Focsani Basin of the Foredeep [53].

The third sub-stage, with the NNW-trending or N-trending axis of compression, had a peak of diastrophism at the Messinian (Figure 6(c)). Systems of the south-verging thrusts developed in the southern slope of the Greater Caucasus and Palmyrides [51]. Folding in the Hellenides and thrusting in the Pamirs were resumed. Content of the coarse clastic material increased in molasses of the intermountain basins of the Central Tien Shan and the Chuya Basin of the Gornyi Altai [6].

During the all sub-stages of the stage 1, the uplands were formed in the zones of compressive deformation concentration. So, these uplands were the results of the compression. Their total area increased in course of time. The relatively fine-grained composition of the molasses and small incisions of that time (not more than first hundreds of meters) indicate that the uplands were not higher with the rare exceptions than mid-level mountains.

To the beginning of the stage 2 , the recent structural pattern of the belt formed finally. Its principal features are the major active faults with mainly strike-slip movements, which indicate the N-S-trending orientation of the maximum compression (Figure 1). The beginning of the stage 2 was accompanied by the rebuilding of the structural pattern of the northern Dead Sea Transform in the north-western Arabia at 4.0 - 3.5 Ma ago [52]. At the same time, the East Anatolian and North Anatolian fault zones as well as the Main Recent Fault of Zagros formed finally, outlining the recent boundaries of the Arabian and Anatolian plates.

The main event of the stage 2 is the sharp acceleration of vertical tectonic movements [6] [57]. The highest rise embraced the Central Asia. For example, the Tibet had the average altitude $\sim 1 \mathrm{~km}$ at the Early Pliocene [58] and the lateritic soil formed in its large parts [59]. However, its average height has reached 3.5 - $4.5 \mathrm{~km}$ since the Late Pliocene. The altitudes of other mountain systems increased two to three times. The coarse molasses began to accumulate in intermountain basins and foredeeps. Beginning of the stage 2 was not synchronous in different mountains [6]. The elevation of the Himalayas more than to $3 \mathrm{~km}$ and the Central Tien Shan to $\sim 2 \mathrm{~km}$ has occurred at the Quaternary (the last $2.5 \mathrm{Ma}$ ). The quick rise of Tibet to 2.5 - $3.6 \mathrm{~km}$ started 3.4 Ma ago. At the same time, the Kunlun and Tarim have risen to 2.6 - $3.1 \mathrm{~km}$ and $\sim 1.2 \mathrm{~km}$, respectively. The Pamirs have grown to $\sim 2 \mathrm{~km}$ during the last 3 - $5 \mathrm{Ma}$. The accelerated uplift of the Altai occurred over the last $\sim 3.5 \mathrm{Ma}$. The topography of the Baikal region mountains became more contrasting at the same time. The intense rise of mountains at the Pliocene-Quaternary was revealed in the Greater Caucasus, the Higher Zagros, the Carpathians, and the Alps [6]. The quick growth of the Coastal and Lebanon ranges was revealed in the Eastern Mediterranean [51].

The acceleration of uplift is not correlated with the acceleration of plate motion and the increase of collisional compression. The intensity of compression decreased in some regions. For example, in the Alps and the Western Carpathians, the collision was completed as early as in the Middle Miocene, whereas the mountains began to grow in the Pliocene-Quaternary against the background of diminished compression. In the Greater Caucasus, the rise accelerated also in the Pliocene-Quaternary against the background of decreasing compression rates recorded in the GPS data [60] [61] and summing offsets on active faults [34]. Even in the regions where the compression increased (the Himalayas, the Pamirs, the Central Tien Shan), the magnitudes of uplift related to the deformational thickening of the crust are only $20 \%-50 \%$ of the total uplift of the land surface (Figure 7). Most intermountain basins rose also, although not so intensely, and this hardly can be a manifestation of compression. Probably, the additional uplift of mountains is caused by other factors.

\section{Analysis of Seismic Tomography Data}

Analysis of seismic tomography data on the north-east Asia [21] [62] [66] has shown that the processed data from the global network of stations, though worse in resolution compared to the data of the regional seismological network, nevertheless give a generally similar pattern. Detailed regional models do not cover big areas. So, 


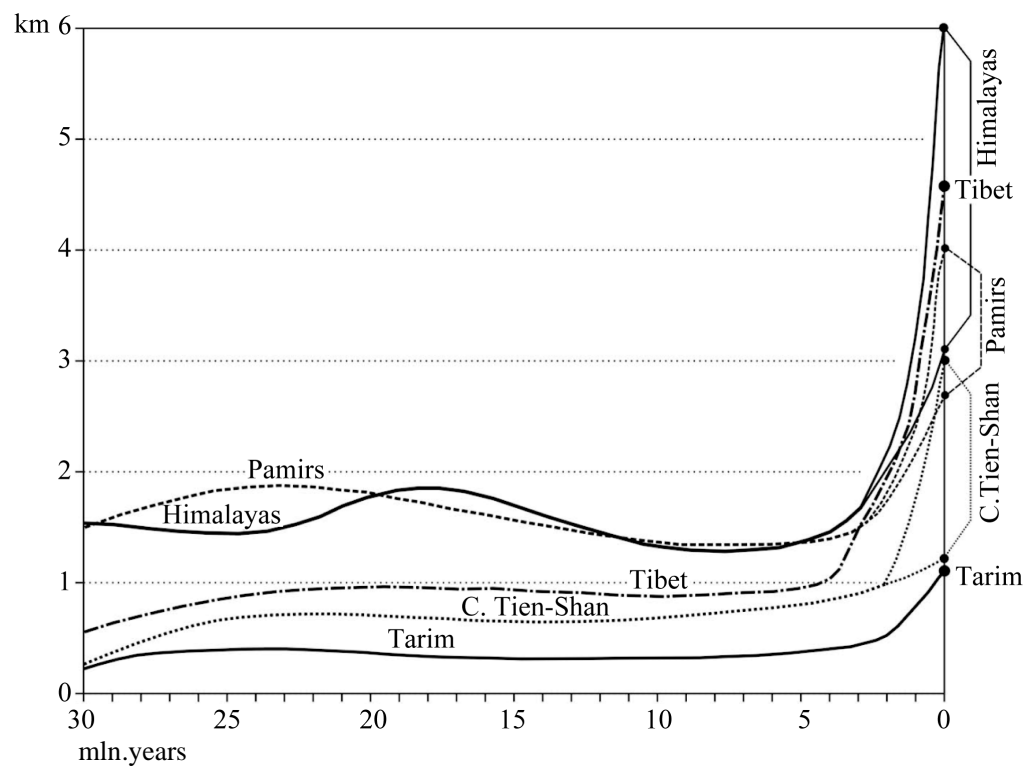

Figure 7. Acceleration of mountain rise in High Asia in the Pliocene-Quaternary. At the right, the lower calculated curves showing what heights would be reached by the Pliocene-Quaternary uplift only as a result of increased compression, are compared with the upper curves showing the actual heights of the Himalayas, Pamirs, and Central Tien Shan.

the models, based on the global network [63]-[65] were used to have uniform resolution within the studied area of Ethiopian-Afar super-plume and Alpine-Himalayan Belt. Their lower spatial resolution in comparison with regional models was considered at the stage of interpretation of the data. For example, it was unable to detect border between lithosphere and asthenosphere. We used other geophysical data for that purpose. On this basis, we interpreted the areas with low average seismic velocities beneath the continents at the depth of $100 \mathrm{~km}$ (Figure 8) as the uplift of asthenosphere top.

The specified data and tomographic models from the global network were used to compile seismic tomographic sections along profile lines shown in Figure 8. Characteristics of anomalous values of $V_{P}$ и $V_{S}$ were performed as deviations from average values per cent. We consider the values of $d V_{P}$ from 0.25 to $0.8 \%$ and the values of $d V_{S}$ from 0.5 to $2.0 \%$, as high anomalies and $d V_{P}>0.8 \%$ and $d V_{S}>2.0 \%$ as very high anomalies. We applied similar constraints for low and very low values. The profiles 1-1' across the Tonga-Kermadek Arc and 2-2' across the Andaman-Indonesian Arc and the Philippines show that the areas of high and very high $d V_{S}$ values corresponding to seismic active slab zones are transformed at depths of $400-800 \mathrm{~km}$ into horizontal high velocity lenses (Figure 9), similar to those, which were detected at the north-eastern margin of Asia [21] [62] [66] and called as "big mantle wedges" (BMW).

Different situation is characteristic of the Tibetan-Himalayan region (Figure 10, sections 3-3'). The layer of very high values of $d V_{S}$ is detected here at the depths down to $100 \mathrm{~km}$ and even $300 \mathrm{~km}$ in some localities. It extends from the Himalayas to the northern margin of the Tien Shan and continues as a high velocity layer beneath the Indian Platform and the Kazakhstan-West Siberian segment of the Eurasian Plate. The high velocity layer thickens to $400 \mathrm{~km}$ beneath the Southern Tibet near the Indus-Tsang Po Zone. One more nearly horizontal high-velocity lens is detected there at depths of $600-700 \mathrm{~km}$. Probably, a part of the thickened upper high velocity layer and this lens are relics of the Neo-Tethys slab that is flattened at the depth. In the $d V_{P}$ section, the high-velocity lens is traced almost from the southern border of the Indian Platform to the northern border of the Tibet at depths of $100-300 \mathrm{~km}$, having the greatest thickness and the highest $d V_{P}$ values also beneath the Southern Tibet. The $d V_{P}$ values in the upper mantle decrease up to average level to the north and one more highvelocity lens appears in the south of West Siberia. A domain of lowered $d V_{P}$ values is situated below the highvelocity layer as a narrow (400 - $500 \mathrm{~km}$ ) lens under the Indian Platform. This domain is reduced under the south of the Tibet and swells to depths of $300-800 \mathrm{~km}$ beneath High Asia from the Tibet to the Tien Shan, 


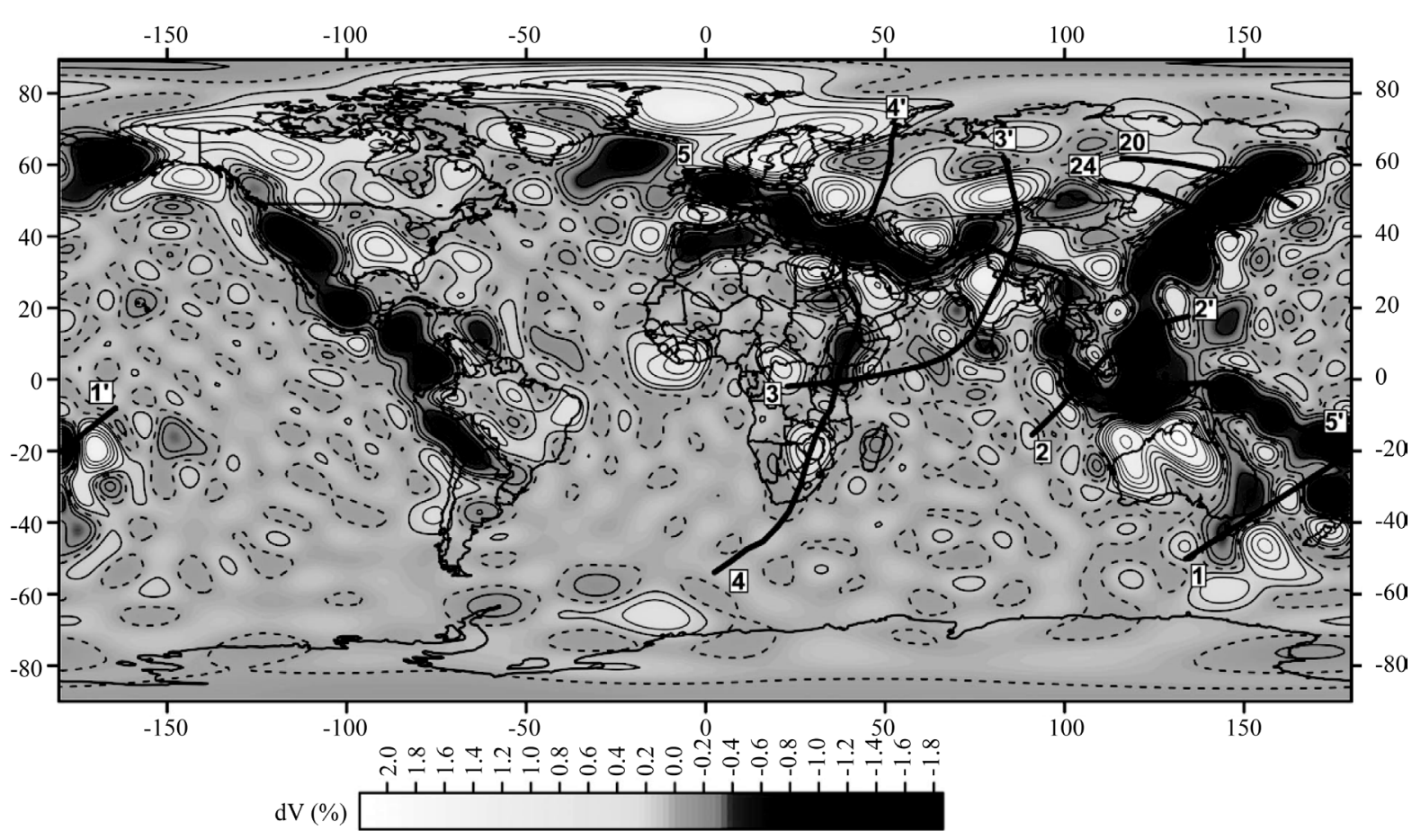

Figure 8. Distribution of $d V_{P}$ at the depth up to $100 \mathrm{~km}$ and lines of sections (Figures 9-12), lines 20 and 24 after [66]. Compiled by S. Yu. Sokolov after the data in [63]-[65]. Contour lines are spaced at $0.2 \%$; the dashed line corresponds to zero value.
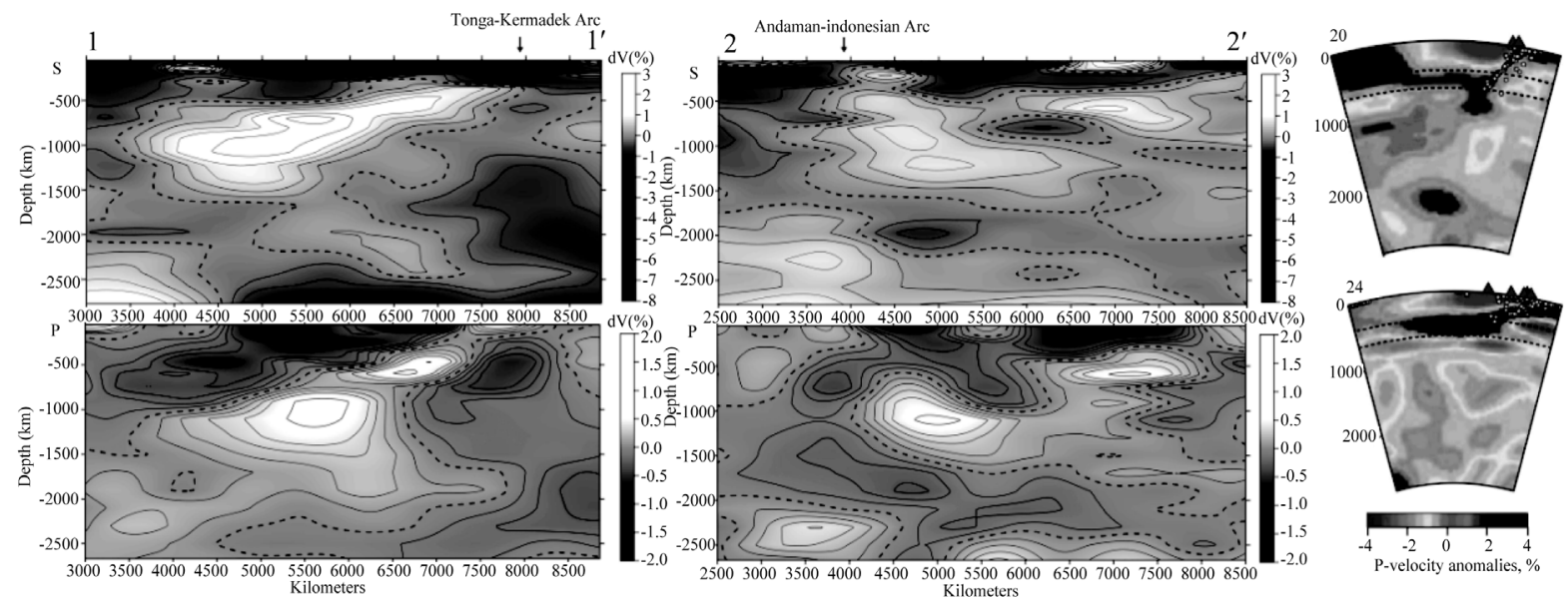

Figure 9. Seismic tomographic $d V_{P}$ and $d V_{S}$ sections along lines: 1-1' across the Tonga-Kermadek Arc; 2-2' across Philippines and the Andaman-Indonesian Arc. Compiled by S. Yu. Sokolov after the data in [63]-[65]. Contour lines are spaced at $0.25 \%$ for $P$-waves and $0.5 \%$ for $S$-waves; the dashed lines correspond to zero value. The $d V_{P}$ profiles across Kamchatka (20) and Khokaido (24) after [62] [66] are given for comparison. Small white circles are hypocenters of earthquakes and dark triangles are volcanoes in the profiles 20 and 24.

where it reaches locally very low values. In the lower mantle under the Tibet, there is unclearly distinguished and fragmented zone of slightly lowered $d V_{P}$ values tilted to the south-west. The above-mentioned features are less distinct in the $d V_{S}$ section, where the tilted lower mantle zone is noted by moderate $d V_{S}$ values against the slightly increased values beneath the adjacent areas.

In the sections across the Ethiopian-Afar super-plume and the Arabian-Iranian segment of the Alpine-Himalayan Belt (Figure 11, sections 4-4'), a relatively thin upper mantle lens of very low $d V_{S}$ values no deeper than $\sim 200 \mathrm{~km}$, is seen beneath the East African rift system and Red Sea Rift up to South Arabia. This lens extends 


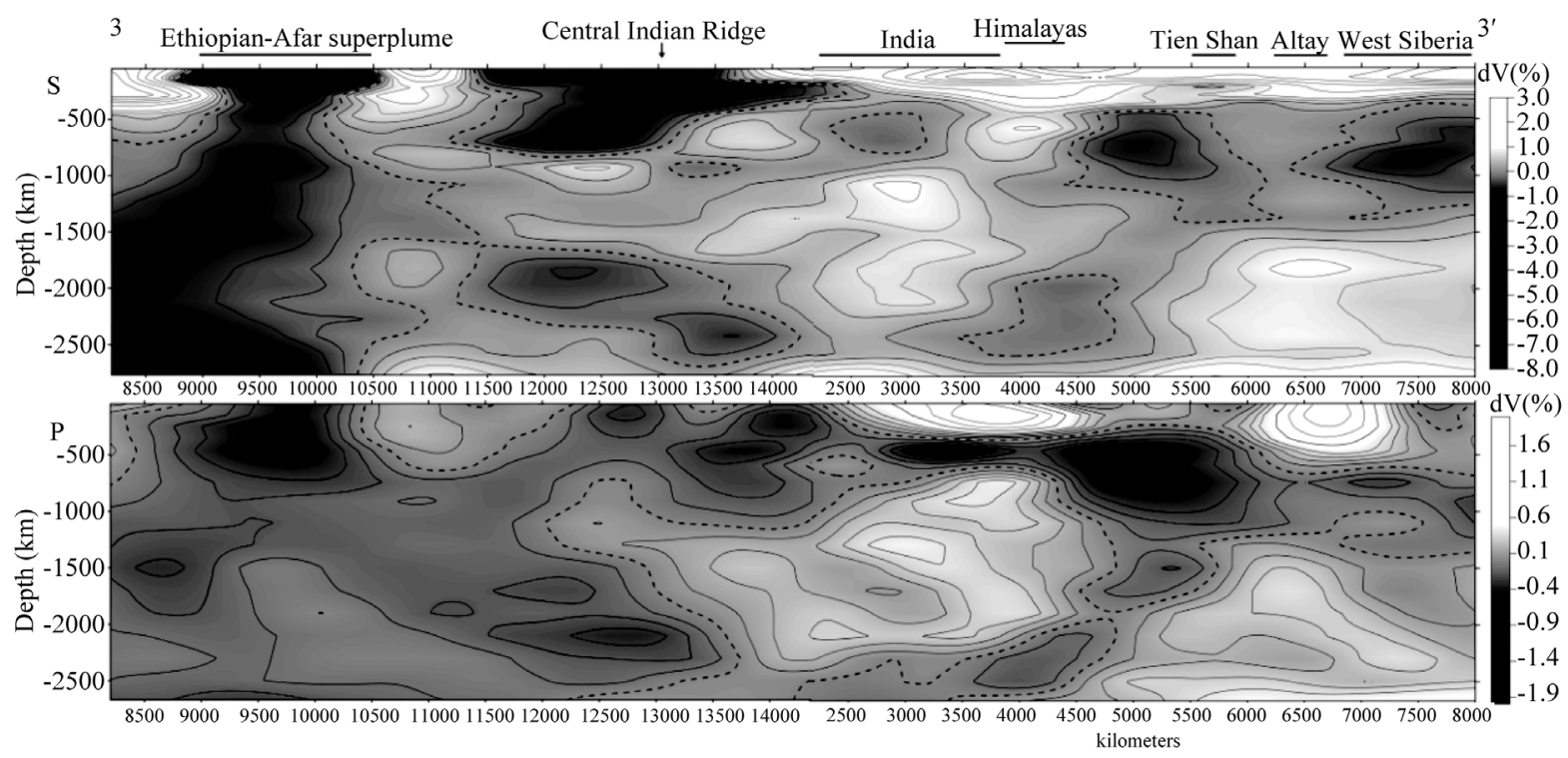

Figure 10. Seismic tomographic $d V_{P}$ and $d V_{S}$ sections along line 3-3' from Kenya via the Mid-Indian Ridge, Indian Platform, and High Asia to the epi-Paleozoic West Siberian Platform. See Figure 9 for legend.

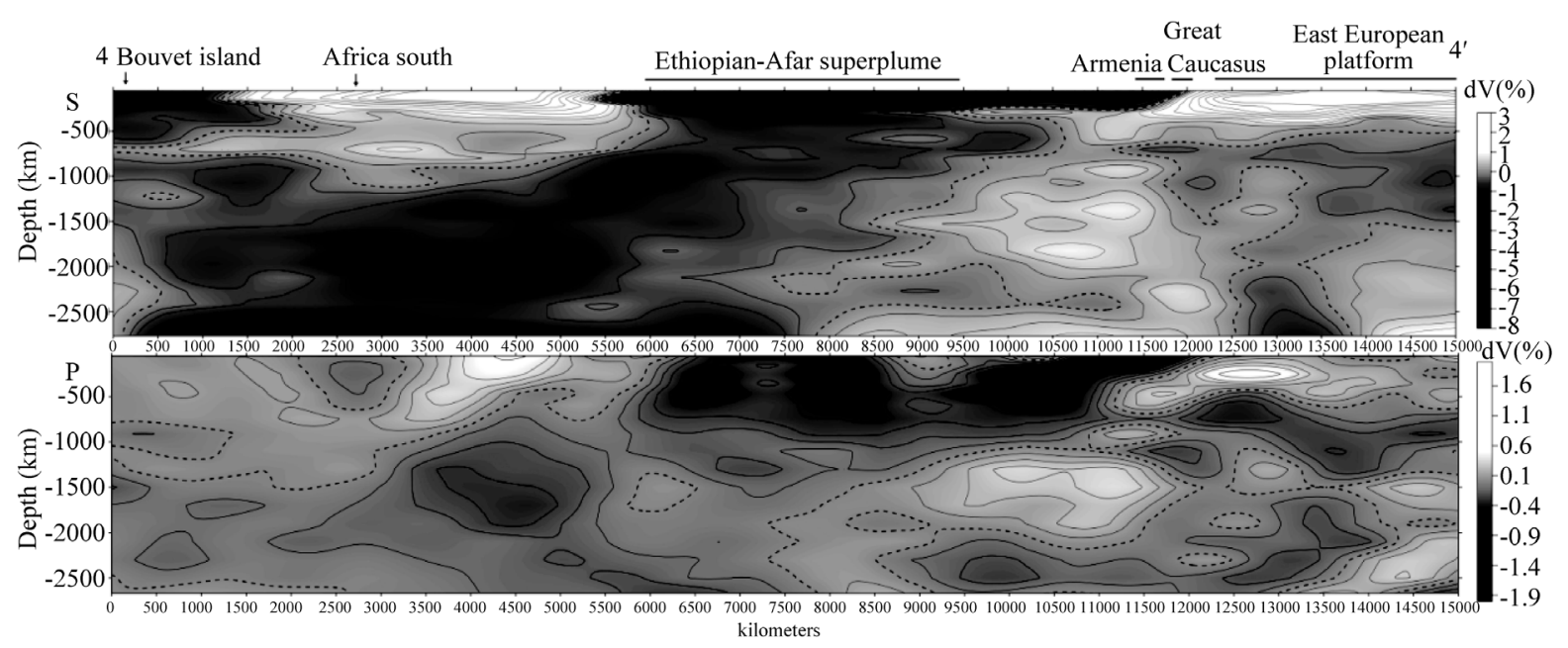

Figure 11. Seismic tomographic $d V_{P}$ and $d V_{S}$ sections along line 4-4' from South Africa via the Ethiopian-Afar super-plume, Arabian Platform and the Caucasus to the East European Platform. See Figure 9 for legend.

northward to the Greater Caucasus, where it is characterized by low $d V_{S}$ values. A wide domain of slightly lowered and locally very low values of $d V_{S}$ is traced down to the bottom of the mantle. The upper part of this domain corresponds to the territory from Malawi up to the Red Sea, and, being tilted to the south, the domain appears beneath South Africa at the lower-mantle level. This domain is regarded as the Ethiopian-Afar superplume. The upper mantle of the African and Eurasian plates is distinguished by increased $d V_{S}$ values. A highvelocity wedge submerges from the Scythian Platform beneath the Greater Caucasus, where the wedge flattens and extends to the Lesser Caucasus, gradually losing its specificity. In the $d V_{P}$ section, the super-plume is also expressed as a wide domain of lowered values tilted to the south. In the upper mantle, the domain is traced down to depths 600 - $800 \mathrm{~km}$ from Malawi to the Lesser Caucasus. Its segments beneath the Kenyan Rift, Afar, and the Armenian volcanic highland are distinguished by very low $d V_{P}$ values. Beneath the Greater Caucasus, the thickness of this domain is abruptly reduced and it is underlaid by the high-velocity wedge deepening from the Scythian Platform. The upper mantle of South Africa and the East European Platform is characterized by slightly increased and average values of $d V_{P}$. 
Sections 5-5' extend along the axis of the Alpine-Himalayan Belt from the Tonga-Kermadek Arc via back-arc basins of the Andaman-Indonesian Arc, the Tibet, the Pamirs, Afganistan, Iran and the Lesser Caucasus to Anatolia and the Carpathians (Figure 12). These sections allow seeing the structures that were detected in the transverse sections, in a new angle. The sections confirm the transition of the Tonga-Kermadek Arc slab into flattened BMW of high $V_{P}$ and $V_{S}$ values at depths of $600-800 \mathrm{~km}$. The section of $d V_{S}$ contains also sub-horizontal high velocity lenses at depths of $\sim 100-200 \mathrm{~km}$ and $350-500 \mathrm{~km}$ in the west margin of the Pacific Ocean and at a depth of $\sim 200 \mathrm{~km}$ between the Papua-New Guinea Arc and the eastern flank of the Andaman-Indonesian Arc. The two-level structure of the Tibet upper mantle (high $V_{P}$ above and lowered $V_{P}$ below) revealed in the transverse sections $3-3^{\prime}$ is approved by the longitudinal section, where such structure is detected over the entire distance from the eastern margin of the Tibet to the Pamirs-Hindu Kush. Westward, from Afghanistan to the Carpathians, a layer of lowered and deeply lowered $d V_{P}$ values is depicted at depths down to $200-300 \mathrm{~km}$ and extends beneath the West European Hercynides. The fact that the same structures are detected in both longitudinal and transverse sections indicates that the revealed velocity variations are related to real mantle heterogeneities rather than to the effect of anisotropic propagation of seismic waves.

The sections 5-5' demonstrate segmentation of the belt known from the relationships between the Late Cenozoic crustal structural elements [34]. This segmentation is expressed better in the $d V_{P}$ section, where the difference of the segments is traced throughout the entire upper mantle. The boundary between the south-eastern "island-arc" and the Tibetan section types approximately coincides with the fault zone of $105^{\circ} \mathrm{E}$ between the corresponding segments of the belt, whereas the boundary between the Tibetan and the Iran-Caucasus section types fits the Darvaz-Chaman fault zone between the Pamir-Himalayan and the Arabian-Iranian segments.

\section{Comparison of the Data and the Sources of Recent Tectonic Uplift}

The Ethiopian-Afar super-plume is a vast N-trending zone occupying the entire East African Rift System in the lithosphere level (Figure 8). The flows of the upper mantle material spread from the super-plume up to the northern margins of the Alpine-Himalayan Belt. The trails of sub-lithosphere flows are marked in the seismic tomography sections across the Arabian-Iranian segment of the belt by the decreased seismic wave velocities throughout the entire upper mantle, the flow being seen better in the $d V_{P}$ section (Figure 11). The flow trails are also seen in the $d V_{P}$ section 3-3' (Figure 10), where the flow layer underlies the thin lithosphere of the Indian Ocean and is covered farther to the north by the high $d V_{P}$ lens corresponding to the thickened lithosphere of the Indian Platform and High Asia. Beneath the flow layer, within the lower mantle, the zone of weakly lowered $d V_{P}$ values is found. Like the Ethiopian-Afar super-plume, this zone dips to the south-west. Perhaps, it is a relic of a previously existing plume.

We suppose that the elongated Ethiopian-Afar super-plume developed as a more or less stationary structure at least from the end of the Paleozoic and could be longer than now before the Cenozoic. The portions of moving Gondwana, which turned out to lie above the super-plume, underwent rifting that developed into spreading, which formed the Tethys Ocean. A flow of heated asthenosphere material from the super-plume caused asym-

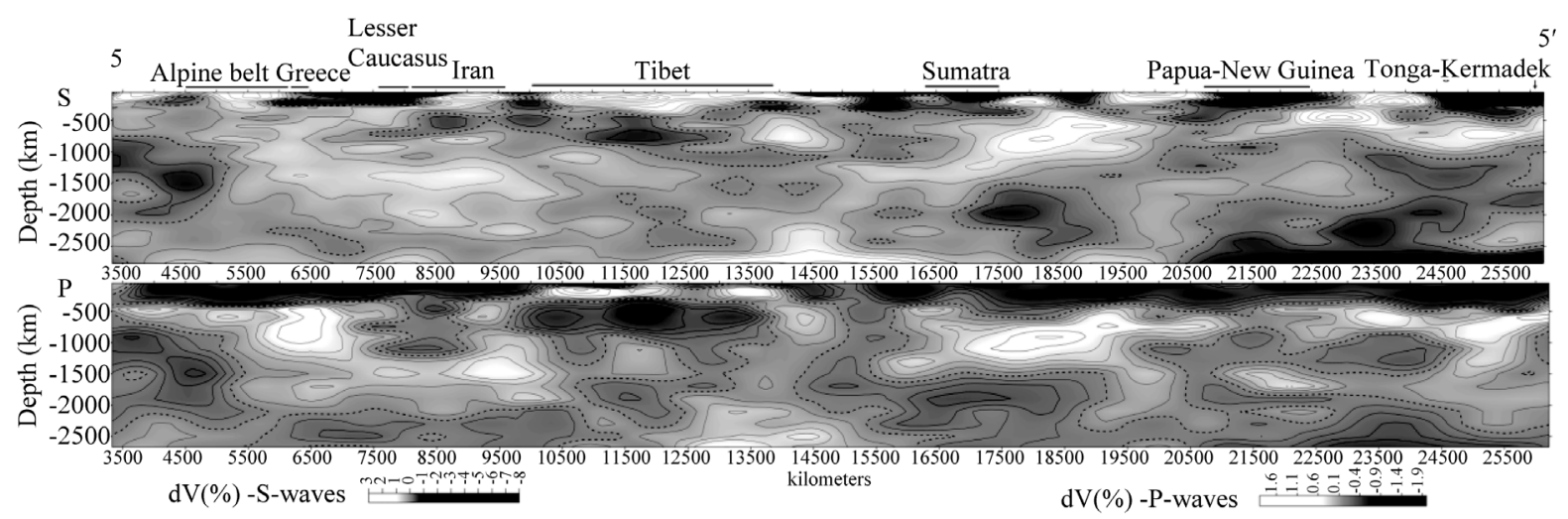

Figure 12. Seismic tomographic $d V_{P}$ and $d V_{S}$ sections along line 5-5' along the Alpine-Himalayan Belt from Tonga-Kermadek Arc via the Indonesian back-arc basin, Tibet, Pamirs, the Lesser Caucasus, Anatolian Plate, and the Carpathians to the West European Hercynides. See Figure 9 for legend. 
metry of the spreading and moving of torn-off fragments of Gondwana to the north-east toward Eurasia. The oceanic Tethyan lithosphere subducted there, the Gondwana fragments accreted to Eurasia, and the subduction zones jumped to their rear (relative to Eurasia) parts. As a result, series of microplates, separated by sutures, accretionary wedges, and magmatic bodies related to different stages of the Tethyan evolution, formed on the place of the future mountain belt. The recent structure of the mantle under the Indonesian segment, where the described process is lasting till now (Figure 9), give a possibility to suppose that the more north-western segments of the belt had previously the same structure, i.e., the subducted slabs transformed there at the depths of 400 - $700 \mathrm{~km}$ into the BMW that extended beneath the future mountain belt. The bulge of the upper high-velocity layer beneath the Southern Tibet (down to $400 \mathrm{~km}$ in the $d V_{S}$ section) and the lower $(\sim 600 \mathrm{~km})$ lens with slightly increased $V_{S}$ may be the BMW relics. In the $d V_{P}$ section, these lenses are separated by the low-velocity layer, which continues the sub-lithosphere flow related to the Ethiopian-Afar super-plume.

The difference between the segments of the Alpine-Himalayan Belt is caused by their different Cenozoic history. The island-arc structure of the Indonesian segment has remained until now, whereas the last relics of the Neo-Tethys in the Pamir-Himalayan segment were closed in the Oligocene. The relics of the Neo-Tethys and the related back-arc basins in the Arabian-Iranian segment were closed at the time from the Late Eocene to the Middle Miocene. Correspondingly, the subduction and the BMW formation gave way in the Pamir-Himalayan and Arabian-Iranian segments to the collision of the Eurasian and Gondwanan lithosphere plates. This process decelerated their convergence, but the hot asthenosphere flow from the Ethiopian-Afar super-plume probably prolonged the former movement and gradually spread under the entire orogenic belt. The propagation developed successively. For example, the sub-lithosphere low-velocity layer thinned sharply beneath the Greater Caucasus. The thinning could have been caused by subduction of the Para-Tethyan Caucasus basins under the Lesser Caucasus before the Middle Miocene [14] [67]. The subduction hindered the northward propagation of the sub-lithosphere flow till the subduction had finished.

The hot sub-lithosphere flows reworked the upper mantle of the Alpine-Himalayan Belt. This is expressed in reduced average $V_{P}$ values in the most upper mantle beneath all mountain systems of the belt, except a part of the Himalayan-Tibetan region (Figure 8). The decrease of the velocities can be interpreted as a thinning of the lithosphere at the expense of the asthenosphere and/or decrease of density in the lithosphere mantle and the lower crust under the effect of the asthenosphere. Beneath High Asia, where the lithosphere was essentially thickened by Cenozoic deformation, the high-velocity layer up to $300-\mathrm{km}$ thick remained above the low- $V_{P}$ layer.

Studies of magmatic rocks of the mantle origin show very low content of water in the magmatic sources [68] [69]. Velocities of seismic waves increase with a depth, changing in the certain levels to portions of kilometer per second. Such jumps are referred to variations of rock density, which cannot be due only to compaction of rocks under the load of overlaying rocks, but suggest the crystalline-chemical transformation of minerals [70]. According to the data of these authors, pyroxenes of mafic and ultramafic rocks are transformed into garnet with a higher density at a depth of $50-100 \mathrm{~km}$. Lower, the most distinct and extensive seismic boundaries occur at depths of $\sim 410 \mathrm{~km}$ and $\sim 670 \mathrm{~km}$, bordering the "transition" layer of the mantle. The $\sim 410-\mathrm{km}$ boundary can mark the transition of orthorhombic olivine to the variety with spinel structure. This is wadsleyite, which has the $8 \%$ higher density and can be transformed into a denser ringwoodite at a depth of $\sim 520 \mathrm{~km}$. Clinopyroxene can be transformed into wadsleyite and stishovite at approximately the same depth. Pyroxenes can acquire a more compact ilmenite-type structure within a depth interval of 410 to $500 \mathrm{~km}$. Deeper $\sim 670 \mathrm{~km}$, these minerals are probably replaced by denser perovskite-type phases occupying $\sim 80 \%$ of the lower mantle. The researchers argue in favor of the idea that the crystalline-chemical structure of wadsleyite and ringwoodite allows replacement of a part of the oxygen atoms in these anhydrous minerals with a hydroxyl group [71] [72]. The subducted slabs, which contain incompletely dehydrated amphibolites and meta-sedimentary rocks and are transformed into the BMW lenses at the 410 - 670-km level, as well as the deeper hydrogen can be sources of the hydroxyl. The appreciable attenuation of shear waves along with insignificant change of their velocities [73] and increased electric conductivity [74] can indicate that fluids occur at those depths.

On moving, the sub-lithosphere flows were enriched in aqueous fluids that could derive from the former BMW lenses related to subduction zones. The asthenosphere, activated in this manner or its fluids penetrated into the lithosphere and gave rise to the following Cenozoic geological processes. The effect of the active asthenosphere and related fluids provoked the formation of intra-lithosphere magmatic sources, including crustal ones [75], and induced softening of the lithosphere [76] that promoted intense deformation, detachment, and 
large lateral displacement resulted in the formation of local uplands in the stage 1 of mountain building. Largescale deformation of the stage 1, accompanied by metamorphism and crustal magmatism caused a consolidation of the Earth's crust to the Early Pliocene. The consolidation was expressed by cessation of the large-scale Pliocene-Quaternary granite formation and localization of volcanic activity within strike-slip zones [77]-[80]. The latter became the leading form of transverse shortening of the belt, whereas the fold-thrust deformation concentrated within the basins with thick sedimentary cover, such as the Sub-Himalayas, Afghan-Tadjik Depression, foothills of the Taurus, the Lower Zagros, and periclines of the Greater Caucasus. Under the consolidated crust, the influence of the asthenosphere onto the lithosphere increased at the stage 2 of mountain building.

According to the seismological and gravimetric data, a density of the uppermost mantle is decreased under the highest mountain systems of Central Asia (the Himalayas, the Tibet, the Kunlun, the Pamir-Hindu Hush-Karakoram region, and the Central and Eastern Tien Shan) [16] [29] [81]-[86]. Kaban M.K. [87] reported the same features in the gravitational field of the Lesser Caucasus. The lowered seismic wave velocities, related to the rise of the asthenosphere were revealed beneath the Eastern Carpathians [53]. According to the Artyushkov's calculations, based on isostatic anomalies of up to $-150 \mathrm{mGal}$ under the Central Tien Shan [82], such decompaction ensures an uplift of $\geq 1.1 \mathrm{~km}$, perhaps, $\geq 1.5 \mathrm{~km}$ [4]. The most probable mechanism of the decompaction is partial replacing of the lithosphere mantle by the lower-dense asthenosphere [1] [4] [5] [76]. The decompaction leads to the uplift of the Earth's crust.

The data on the Central Tien Shan lead us to presume the influence of one more factor intensifying the uplift [4]. As it is shown in paragraph 2.2, the Late Cenozoic compression thickened the Earth's crust up to 47 - 50 $\mathrm{km}$. However, now the crust of the CTS is thicker: from 40 - $52 \mathrm{~km}$ under the basins up to 52 - $64 \mathrm{~km}$ under the ridges [13] [88] [89]. Hence, the thickening is due not only to compression, but also to crustal growth from the bottom owing to the rocks, which had a near-mantle density before. They might be paleo-oceanic mafic rocks that metamorphosed under the tectonically thickened crust to garnet granulites and eclogites. Retrograde metamorphism (serpentinization of ultramafic rocks, amphibolitization of granulites, etc.) was sharply accelerated by fluids and led to the decompaction of the meta-mafic rocks, which incorporated into the crust. The crust thickened the most under the ridges, where the decompacted mantle is closest to the crust bottom [16] [89]. Since relics of the oceanic crust are widespread in the Alpine-Himalayan Belt, such transformation might have intensified their uplift considerably [2] [90].

Influence of this factor seems to be dominant on the additional uplift of the Greater Caucasus above that due to the compressional deformation. The decompaction of the most upper mantle is found only under the Elbrus volcanic region [91]. At the same time, volumes of rocks with the lowered density and increased electric conductivity were found under the Central and Eastern Caucasus in the lower crust and near the crust-mantle boundary [45]. Such volume under Elbrus at the depths of $35-50 \mathrm{~km}$ is characterized by the lower seismic wave velocities and is identified as a magmatic source [92]. However, this interpretation cannot be applied to the other similar volumes. Their decompaction is probably due to the retrograde metamorphism of rocks near the crustmantle boundary with participation of the cooled asthenosphere fluids. Their main source was the asthenosphere flow from the Ethiopian-Afar super-plume that reached the Greater Caucasus only in the Late Miocene [93]. Small thickness of the flow explains its weak expression in the field of seismic wave velocities. However, this thin flow and its fluid influence were able to facilitate metamorphic decompaction of the high-grade metamorphic rocks of the crustal origin that resulted in the uplift of mountain system. We suppose the same development of the Late Cenozoic tectonic processes in the Western Tien Shan [6].

\section{Conclusions}

The history of tectonic uplift resulting in mountain building is analyzed against the background of the entire tectonic evolution of the Alpine-Himalayan Belt from the Eocene until now. The detailed studies in the Central Tien Shan and the Greater Caucasus together with the data on the entire central part of the belt showed that tectonic uplift began in the Oligocene and developed being divided into two stages. During the first stage consisting of three sub-stages with different orientations of compression, local uplifts, usually not higher than middleelevated mountains, occurred in the zones of concentration of the compression, and their total area was increasing with time. During the second stage (the last 2 - $5 \mathrm{Ma}$, i.e., different time intervals in different regions), the accelerated uplift embraced areas not uplifted earlier, and coarse molasses began to accumulate in intermountain and foreland basins. The paleo-tectonic maps for the Eocene ( $\sim 5 \mathrm{Ma}$ ), the Late Oligocene ( $25 \mathrm{Ma}$ ), the Middle Miocene ( $\sim 18 \mathrm{Ma}$ ), and the Late Miocene ( $\sim \mathrm{Ma}$ ), and the map of the Pliocene-Quaternary tectonics of the 
central part of the belt illustrate development of this process.

GPS, geomorphological and geological data on the Pliocene-Quaternary tectonics brought together show that the acceleration in majority of mountain systems of the belt cannot be explained by only the increase of collisional compression and related deformational thickening of the Earth's crust. Although the compression did increase in some systems, as the Himalayas, Pamirs and Tien Shan, the geophysical data suggest that compression was accompanied by decompaction of rocks of the lower crust and the lithosphere mantle. To find sources of this decompaction and, correspondingly, the additional rise, we analyzed the seismic tomography data on the mantle in the Eastern Hemisphere. These data indicate that there are lateral asthenosphere flows, under the Alpine-Himalayan Belt, which start from the Ethiopian-Afar super-plume. We suggest that the flows spread beneath the belt after closing of the Neo-Tethys and the beginning of the total collision of the Gondwanan plates and Eurasia, and, on moving, rebuilt the former upper mantle, including the 400 - 700-km deep transition layer enriched with aqueous fluid. Dewatering of the transition layer and enriching of the asthenosphere flows by the fluid sources caused their activity.

The activated flows and their fluids may have softened the lithosphere and facilitated its detachment and subsequent deformational thickening of the Earth's crust and then tectonic uplift in areas of maximum compression. During the first stage, compression was the only or, at least, the main source of uplift. During the second stage (the last 5 - $2 \mathrm{Ma}$ ), the deformational effect was supplemented by two other processes that were initiated by the sub-lithosphere flows and their fluids. The first process was the partial replacing of the lithosphere mantle by low-density asthenosphere material and, as a result, decompaction of the uppermost mantle. The second process was the retrograde metamorphism of high-metamorphosed rocks of the crustal origin within the lower crust and near the crust-mantle boundary with participation of the asthenosphere fluids and, as a result, decompaction of these rocks. Both processes produced additional uplift of the land surface and caused the acceleration of total uplift of the belt during the Pliocene-Quaternary. Proportion between the two processes varied from region to region, so that the Central Tien Shan rose due to mainly partial replacing of the lithosphere mantle by the asthenosphere material, while the uplift of the Greater Caucasus was caused first of all by retrograde metamorphism of high-metamorphosed rocks within the lower crust and near the crust-mantle boundary.

\section{Acknowledgements}

This study was supported by the Division of Earth Sciences, Russian Academy of Sciences (program no. 6), the Presidium of the RAS (program no. 4), and the Russian Foundation for Basic Research (projects no. 11-0500628-a and 14-05-00122).

\section{References}

[1] Artyushkov, E.V. (1993) Physical Tectonics. Nauka, Moscow, 456 p. (in Russian)

[2] Sokolov, S.Y. and Trifonov, V.G. (2012) Role of the Asthenosphere in Transfer and Deformation of the Lithosphere: The Ethiopian-Afar Superplume and the Alpine-Himalayan Belt. Geotectonics, 46, 171-184. http://dx.doi.org/10.1134/S0016852112030053

[3] Trifonov, V.G. (2012) Problems of Mountain Building: Alpine-Himalayan Belt. In: Tectonophysics and Actual Problems of the Earth Sciences 1, Institute of Physics of the Earth, Moscow, 99-109. (in Russian)

[4] Trifonov, V.G., Artyushkov, E.V., Dodonov, A.E., Bachmanov, D.M., Mikolaichuk, A.V. and Vishnyakov, F.A. (2008) Pliocene-Quaternary Orogeny in the Central Tien Shan. Russian Geology and Geophysics, 49, 98-112. http://dx.doi.org/10.1016/j.rgg.2007.06.012

[5] Trifonov, V.G., Ivanova, T.P. and Bachmanov, D.M. (2012) Evolution of the Central Part of the Alpine-Himalayan BeIt in the Late Cenozoic. Russian Geology and Geophysics, 53, 289-304.

[6] Trifonov, V.G., Ivanova, T.P. and Bachmanov, D.M. (2012) Recent Mountain Building in Geodynamic Evolution of the Central Alpine-Himalayan Belt. Geotectonics, 46, 315-332. http://dx.doi.org/10.1134/S0016852112050068

[7] Bazhenov, M.L. and Burtman, V.S. (1990) Structural Arcs of the Alpine Belt: Carpathians-Caucasus-Pamirs. Nauka, Moscow, 167 p. (in Russian)

[8] Trifonov, V.G. (1999) Neotectonics of Eurasia. Nauchnyi Mir, Moscow, 254 p. (in Russian)

[9] Burtman, V.S. and Samygin, S.G. (2001) Tectonic Evolution of High Asia in the Paleozoic and Mesozoic. Geotectonics, 35, 276-294. 
[10] Ivanova, T.P. and Trifonov, V.G. (2005) Neotectonics and Mantle Earthquakes in the Pamir-Hindu Kush Region. Geotectonics, 39, 56-68.

[11] Molnar, P. and Chen, W.P. (1978) Evidence for Large Cenozoic Crustal Shortening of Asia. Nature, 273, $218-220$. http://dx.doi.org/10.1038/273218a0

[12] Golonka, J. (2004) Plate Tectonic Evolution of the Southern Margin of Eurasia in the Mesozoic and Cenozoic. Tectonophysics, 381, 235-273. http://dx.doi.org/10.1016/j.tecto.2002.06.004

[13] Robertson, A., Unlügenç, Ü.C., Inan, N. and Taśli, K. (2004) The Misis-Andirin Complex: A Mid-Tertuary Melange Related to Late-Stage Subduction of the Southern Neotethys in S Turkey. Journal of Asian Earth Sciences, 22, 413-453. http://dx.doi.org/10.1016/S1367-9120(03)00062-2

[14] Leonov, Y.G. (Ed.) (2007) Alpine History of the Great Caucasus. GEOS, Moscow, 368 p. (in Russian)

[15] Kaz’min, V.G., Lobkovsky, L.I. and Tikhonova, N.F. (2010) Late Cretaceous-Paleogene Deepwater Basin of North Afganistan and the Central Pamirs: Issue of Hindu Kush Earthquakes. Geotectonics, 44, 127-138. http://dx.doi.org/10.1134/S0016852110020032

[16] Gubin, I.E. (Ed.) (1986) Lithosphere of the Tien Shan. Nauka, Moscow, 158 p. (in Russian)

[17] Shults, S.S. (1948) Analysis of Neotectonics and Relief of Tien Shan. Geographgiz, Moscow, 224 p. (in Russian)

[18] Makarov, V.I. (1977) Recent Tectonic Structure of the Central Tien Shan. Nauka, Moscow, 172 p. (in Russian)

[19] Krestnikov, V.N., Belousov, T.P., Ermilin, V.I., Chigarev, N.V. and Shtange, D.V. (1979) The Quaternary Tectonics of the Pamirs and Tien Shan. Nauka, Moscow, 116 p. (in Russian)

[20] Dmitriyeva, E.L. and Nesmeyanov, S.A. (1982) Mammals and Stratigraphy of Tertiary Continental Deposits in SouthEastern Middle Asia. Nauka, Moscow, 140 p. (in Russian)

[21] Chediya, O.K. (1986) Morphostructures and Recent Tectogenesis of the Tien Shan. Ilim, Frunze, 315 p. (in Russian)

[22] Krylov, A.Y. (1960) The Absolute Age of Rocks of the Central Tien Shan and Application of the Ar Method to Metamorphic and Sedimentary Rocks. Proceedings of the 21st IGC. Publ. of Academy of Sciences of the USSR, Moscow, 222-244. (in Russian)

[23] Simonov, V.A., Mikolaichuk, A.V., Kovyazin, S.V., Travin, A.V., Buslov and M.M., Sobel, E.R. (2005) Meso-Cenozoic Plume Magmatism in the Central Tien Shan: Age and Physicochemical Characteristics. In: Geodynamics and Geoecology of the Highland Regions in the 21st Century. The 3rd International Symposium. Scientific Station of the Russian Academy of Sciences, Bishkek, 182-186. (in Russian)

[24] Bachmanov, D.M., Trifonov, V.G., Mikolaychuk, A.V., Vishnyakov, F.A. and Zarshchikov, A.A. (2008) The Minkush-Kökömeren Zone of Recent Transpression in the Middle Tien Shan. Geotectonics, 42, 186-205. http://dx.doi.org/10.1134/S0016852108030035

[25] Bachmanov, D.M., Trifonov, V.G., Mikolaychuk, A.V., Dodonov, A.E., Zarshchikov, A.A. and Vishnyakov, F.A. (2009) Neotectonic Evolution of the Central Tien Shan by the Data on Structure of Late Cenozoic Basins. In: Geodynamics of Intra-Continental Orogens and Geo-Ecological Problems, Scientific Station of the RAS, Bishkek, 12-19. (in Russian)

[26] Yakovlev, F.L. (2012) Reconstruction of the Balanced Structure of the Eastern Part of Alpine Greater Caucasus Using Data from Quantitative Analysis of Linear Folding-Case Study. Bulletin of Kamchatka Regional Association "Educational-Scientific Center", Earth Science, 19, 191-214. (in Russian)

[27] Yin, A., Nie, S., Craig, P., Harrison, T.M., Ruerson, F.J., Xianglin, Q. and Geng, Y. (1998) Late Cenozoic Tectonic Evolution of the Southern Chinese Tien Shan. Tectonics, 17, 1-27. http://dx.doi.org/10.1029/97TC03140

[28] Zubovich, A.V., Trapeznikov, Y.A., Bragin, V.D., Mosienko, O.I., Shchelochkov, G.G., Rybin, A.K. and Batalev, V.Y. (2001) Deformation Field, Deep Crustal Structure, and Spatial Seismicity Distribution in the Tien Shan. Russian Geology and Geophysics, 42, 1550-1557.

[29] Laverov, N.P. and Makarov, V.I. (Eds.) (2005) Recent Geodynamics of Intra-Continental Areas of Collisional Orogeny (Central Asia). Nauchnyi Mir, Moscow, 400 p. (in Russian)

[30] Zubovich, A.V., Wang, X., Scherba, Y.G., Schelochkov, G.G., Reilinger, R., Reigber, C., Mosienko, O.I., Molnar, P., Michaljow, W. and Makarov, V.I. (2010) GPS Velocity Field for the Tien Shan and Surrounding Regions. Tectonics, 29, Article No. TC6014.

[31] Burtman, V.S. (2012) Geodynamics of Tibet, Tarim, and the Tien Shan in the Late Cenozoic. Geotectonics, 46, 185211. http://dx.doi.org/10.1134/S0016852112030028

[32] Molnar, P. and Ghose, S. (2000) Seismic Moment of Major Earthquakes and the Rate of Shortening across the Tien Shan. Geophysical Research Letters, 27, 2377-2380. http://dx.doi.org/10.1029/2000GL011637

[33] Abdrakhmatov, K.E., Weldon, R., Thompson, S., Burbank, D., Rubin, Ch., Miller, M. and Molnar, P. (2001) Onset, 
Style, and Current Rate of Shortening in the Central Tien Shan (Kyrgyzstan). Russian Geology and Geophysics, 42 , 1502-1526.

[34] Trifonov, V.G., Soboleva, O.V., Trifonov, P.V. and Vostrikov, G.A. (2002) Recent Geodynamics of the Alpine-Himalayan Collision Belt. GEOS, Moscow, 225 p.

[35] Milanovsky, E.E. and Khain, V.E. (1963) Geological Structure of the Caucasus. Lomonosov’s University Press, Moscow, 358 p. (in Russian)

[36] Panov, D.I. (1988) Structural-Facial Zoning of the Greater Caucasus at the Early-Alpine Stage of Evolution (Early and Middle Jurassic). Bulletin of the Moscow Society for Natural Research, Geological Section, 63, 13-24. (in Russian)

[37] Scherba, I.G. (1993) Stages and Phases of Cenozoic Development of Alpine Fold Belt. Nauka, Moscow, 231 p. (in Russian)

[38] Marinin, A.V. and Rastsvetaev, L.M. (2008) Strustural Parageneses of North-Western Caucasus. Problems of Tectonophysics, Institute of Physics of the Earth, Moscow, 191-224. (in Russian)

[39] Gamkrelidze, P.D. and Gamkrelidze, I.P. (1965) Tectonic Nappes in the Southern Slope of the Greater Caucasus. Proceedings of Geological Institute of the Georgian Academy of Sciences, New Series 57, Metsniereba, Tbilisi. (in Russian)

[40] Panov, D.I. (2002) Tectonic Structure of the Jurassic Terrigenious Complex of the Greater Caucasus: Mechanism and Age of Formation. Proceedings of the North-Caucasus Technical University, Series of Tectonics \& Geodynamics, No. 1, 60-70. (in Russian)

[41] Yakovlev, F.L. (2006) Design of Relief of the Cover/Basement Surface, According to Estimation of Value of Fold Structure Shortening. In: Regions of Active Tectonogenesis in Recent and Old History of the Earth, Vol. 2, GEOS, Moscow, 411-415. (in Russian)

[42] Yakovlev, F.L. (2008) First Variant of the 3D Model of Sedimentary Cover Structure in the North-Western Caucasus, According to the Data on Fold Deformation Field. Problems of Tectonophysics, Institute of Physics of the Earth, Moscow, 335-345. (in Russian)

[43] Kopp, M.L. and Scherba, I.G. (1993) Relationships of Tectonic and Eustatic Factors in Development of the Cenozoic Basins of the Northern Mediterranean Belt. Bulletin of the Moscow Society for Natural Research, Geological Section 68, 15-31. (in Russian)

[44] Krasnopevtseva, G.V. (1984) Deep Structure of the Caucasus Seismically Active Region. Nauka, Moscow, 109 p. (in Russian)

[45] Grekov, I.I., Korsakov, S.G., Kompaniets, M.A., Lavrishchev, V.A., Pis’mennyi, A.N. and Semenukha, I.N. (2008) Geoelectric Model of the Earth's Crust of the Russian Sector of the Greater Caucasus. In: General and Regional Problems of Tectonics and Geodynamics 1, GEOS, Moscow, 239-244. (in Russian)

[46] Milanovsky, E.E. (1968) Neotectonics of Caucasus. Nedra, Moscow, 483 p. (in Russian)

[47] Polkanova, L.P. (Ed.) (1971) Map of Neotectonics of the South of the USSR, Scale 1:1000000. VNIGNI, Leningrad.

[48] Dronov, V.I. (1980) Geology and Mineral Resources of Afghanistan. Book 1: Geology, Nedra, Moscow. (in Russian)

[49] Aitchison, J.C., Ali, J.R. and Davis, A.M. (2007) When and Where Did India and Asia Collide? Journal of Geophysical Research, 112, 1-19.

[50] Devyatkin, E.V. (1965) Cenozoic Sedimentary Rocks and Neotectonics of the Southeastern Altai. Nauka, Moscow. (in Russian)

[51] Trifonov, V.G. (Ed.) (2012) Neotectonics, Recent Geodynamics and Seismic Hazard of Syria. GEOS, Moscow, 204 p.

[52] Rukieh, M., Trifonov, V.G., Dodonov, A.E., Minini, H., Ammar, O., Ivanova, T.P., Zaza, T., Yusef, A., Al-Shara, M. and Jobaili, Y. (2005) Neotectonic Map of Syria and Some Aspects of Late Cenozoic Evolution of the North-Western Boundary Zone of the Arabian Plate. Journal of Geodynamics, 40, 235-256. http://dx.doi.org/10.1016/j.jog.2005.07.016

[53] Artyushkov, E.V., Baer, M.A. and Mörner, N.A. (1996) The East Carpathians: Indications of Phase Transitions, Lithospheric Failure and Decoupled Evolution of Thrust Belt and Its Foreland. Tectonophysics, 262, 101-132. http://dx.doi.org/10.1016/0040-1951(95)00207-3

[54] Searle, M.P. (1996) Cooling History, Exhumation and Kinematics of the Himalaya-Karakorum-Tibet Orogenic Belt. In: Yin, A. and Harrison T.M., Eds., The Tectonic Evolution of Asia, Cambridge University Press, Cambridge, 110-137.

[55] Tapponnier, P., Mattauer, M., Proust, F. and Cassaigneau, C. (1981) Mesozoic Ophiolites, Sutures, and Arge-Scale Tectonic Movements in Afghanistan. Earth and Planetary Science Letters, 52, 355-371. http://dx.doi.org/10.1016/0012-821X(81)90189-8

[56] Bogachkin, B.M. (1981) History of Tectonic Evolution of the Gorni Altai in Cenozoic. Nauka, Moscow. (in Russian) 
[57] Ollier, C.D. (2006) Mountain Uplift and the Neotectonic Period. Annales of Geophysics, 49, 437-450.

[58] Li, J.J., Shi, Y.F. and Li, B.Y. (1995) Uplift of the Qinghai-Xizang (Tibet) Plateau and Global Change. University Press, Lanzhou, $168 \mathrm{p}$.

[59] He, M. and He, K. (1987) The Planation Surface of the Yunnan Plateau and Its Neotectonic Significance. Annals of Geomorphology. Neue Folge., 63, 51-56.

[60] Shevchenko, V.I., Guseva, T.V., Lukk, A.A., Mishin, A.V., Prilepin, M.T., Reilinger, R.E., Hamburger, M.W., Shempelev, A.G. and Yunga, S.L. (1999) Recent Geodynamics of Caucasus by the Results of the GPS Measurements and Seismological Data. Physics of the Earth, 9, 3-18. (in Russian)

[61] McClusky, S.C., Balassanian, S., Barka, A.A., Ergintav, S., Georgie, I., Gurkan, O., Hamburger, M., Hurst, K., Kahle, H., Kastens, K., Kekelidse, G., King, R., Kotzev, V., Lenk, O., Mahmout, S., Mishin, A., Nadaria, M., Ouzounis, A., Paradisissis, D., Peter, Y., Prilepin, M., Reilinger, R.E., Sanli, I., Seeger, H., Teableb, A., Toksöz, N. and Veis, V. (2000) Global Positioning System Constraints on Plate Kinematics and Dynamics in the Eastern Mediterranean and Caucasus. Journal of Geophysical Research, 105, 5695-5719.

[62] Zhao, D. (2009) Multiscale Seismic Tomography and Mantle Dynamics. Gondwana Research, 15, 297-323. http://dx.doi.org/10.1016/j.gr.2008.07.003

[63] Becker, T.W. and Boschi, L.A (2002) A Comparison of Tomographic and Geodynamic Mantle Models. Geochemistry, Geophysics, Geosystems, 3, Paper No. 2001GC000168.

[64] Grand, S.P., Van der Hilst, R.D. and Widiyantoro, S. (1997) Global Seismic Tomography: A Snapshot of Convection in the Earth. GSA Today, 7, 1-7.

[65] Van der Hilst, R.D., Widiyantoro, S. and Engdahl, E.R. (1997) Evidence of Deep Mantle Circulation from Global Tomography. Nature, 386, 578-584. http://dx.doi.org/10.1038/386578a0

[66] Zhao, D., Pirajno, F., Dobretsov, N.L. and Liu, L. (2010) Mantle Structure and Dynamics under East Russia and Adjacent Regions. Russian Geology and Geophysics, 51, 925-938. http://dx.doi.org/10.1016/j.rgg.2010.08.003

[67] Leonov, M.G. (1975) Wild Flysch of the Alpine Region. Nauka, Moscow, 149 p. (in Russian)

[68] Ringwood, A.E. (1975) Composition and Petrology of the Earth’s Mantle. McGraw-Hill, London, New York and Sydney, 618 p.

[69] Ryabchikov, I.D. (2005) Mantle Magmas as a Sensor of the Composition of Deep Geospheres. Geology of Ore Deposits, 47, 455-468.

[70] Pushcharovsky, Y.M. and Pushcharovsky, D.Y. (2010) Geology of the Earth’s Mantle. GEOS, Moscow, 140 p. (in Russian)

[71] Smyth, J.R. (1994) A Crystallographic Model for Hydrous Wadsleyte: An Ocean in the Earth’s Interior? American Mineralogist, 79, 1021-1025.

[72] Jacobsen, S.D., Demouchy, S., Frost, J.D., Ballaran, T.B. and Kung, J. (2005) A Systematic Study of OH in Hydrous Wadsleite from Polarized FTIR Spectroscopy and Single-Crystal X-Ray Diffraction: Oxygen Sites for Hydrogen Storage in Earth's Interior. American Mineralogist, 90, 61-70. http://dx.doi.org/10.2138/am.2005.1624

[73] Lawrence, J.F. and Wysession, M.E. (2006) Seismic Evidence for Subduction Transported Water in the Lower Mantle. In: Jacobsen, S.V. and van der Lee S., Eds., Earth Deep Water Cycle, Geophysical Monograph Series 168, John Wiley \& Sons, Hoboken, 251-261.

[74] Kelbert, A., Schultz, A. and Egbert, G. (2009) Global Electromagnetic Induction Constraints on Transition-Zone Water Content Variations. Nature, 469, 1003-1006. http://dx.doi.org/10.1038/nature08257

[75] Letnikov, F.A. (2003) Magma-Forming Fluid Systems of Continental Lithosphere. Russian Geology and Geophysics, 44, 1219-1225.

[76] Artyushkov, E.V. (2003) Abrupt Continental Lithosphere Weakening as a Precondition for Fast and Large-Scale Tectonic Movements. Geotectonics, 37, 107-123.

[77] Koronovsky, N.V. and Demina, L.I. (1999) Collision Stage of the Evolution of the Caucasian Sector of the Alpine Foldbelt: Geodynamics and Magmatism. Geotectonics, 33, 102-118.

[78] Karakhanian, A., Djrbashian, R., Trifonov, V., Philip, H., Arakelian, S. and Avagyan, A. (2002) Holocene-Historical Volcanism and Active Faults as Natural Risk Factor for Armenia and Adjacent Countries. Journal of Volcanology and Geothermal Research, 113, 319-344. http://dx.doi.org/10.1016/S0377-0273(01)00264-5

[79] Wang, Y., Zhang, X.M., Jiang, C.S., Wei, H.Q. and Wan, J.L. (2007) Tectonic Controls on the Late Miocene-Holocene Volcanic Eruptions of the Tengchong Volcanic Field along the Southeastern Margin of the Tibetan Plateau. Journal of Asian Earth Sciences, 30, 375-389. http://dx.doi.org/10.1016/j.jseaes.2006.11.005

[80] Trifonov, V.G., Dodonov, A.E., Sharkov, E.V., Golovin, D.I., Chernyshev, I.V., Lebedev, V.A., Ivanova, T.P., Bach- 
manov, D.M., Rukieh, M., Ammar, O., Minini, H., Al Kafri, A.M. and Ali, O. (2011) New Data on the Late Cenozoic Basaltic Volcanism in Syria, Applied to Its Origin. Journal of Volcanology and Geothermal Research, 199, 177-192. http://dx.doi.org/10.1016/j.jvolgeores.2010.01.013

[81] Artemjev, M.E. (1975) Isostasy of the USSR Territory. Nauka, Moscow, 215 p. (in Russian).

[82] Artemjev, M.E. and Kaban, M.K. (1994) Density Inhomogeneities, Isostasy and Flexural Rigidity of the Lithosphere in the Transcaspian Region. Tectonophysics, 240, 281-297. http://dx.doi.org/10.1016/0040-1951(94)90276-3

[83] Vinnik, L.P., Lukk, A.A. and Nersesov, I.L. (1977) Nature of the Intermediate Seismic Zone in the Mantle of the Pamir-Hindu-Kush. Tectonophysics, 38, T9-T14. http://dx.doi.org/10.1016/0040-1951(77)90208-6

[84] Vinnik, L.P., Reigber, C., Aleshin, I.M., Kosarev, G.L., Kaban, M.K., Oreshin, S.I. and Roecker, S.V. (2004) Receiver Function Tomography of the Central Tien Shan. Earth and Planetary Science Letters, 225, 131-146. http://dx.doi.org/10.1016/j.epsl.2004.05.039

[85] Jiménez-Munt, I., Fernàndez, M., Vergés, J. and Platt, J.P. (2008) Lithosphere Structure underneath the Tibetan Plateau Inferred from Elevation, Gravity and Geoid Anomalies. Earth and Planetary Science Letters, 267, 276-289. http://dx.doi.org/10.1016/j.epsl.2007.11.045

[86] Li Z.W., Roeker, S., Li Z.H., Wei B., Wang H.T., Schelochkov, G. and Bragin, V. (2009) Tomographic Image of the Crust and upper Mantle beneath the Western Tien Shan from the MANAS Broadband Deployment: Possible Evidence for Lithospheric Delamination. Tectonophysics, 477, 1-102.

[87] Kaban, M.K. (2000) Gravitational Model of the Lithosphere and Geodynamics. In: Grachev, A.F., Ed., Neotectonics, Geodynamics and Seismicity of the Northern Eurasia, Institute of Physics the Earth of the RAS and GEON, Moscow, 267-290. (in Russian)

[88] Makarov, V.I., Alekseev, D.V., Batalev, V.Yu., Bataleva, E.A., Belyaev, I.V., Bragin, V.D., Dergunov, N.T., Efimova, N.N., Leonov, M.G., Munirova, L.M., Pavlenkin, A.D., Roeker, S.V., Roslov, Yu.V., Pybin, A.K. and Schelochkov, G.G. (2010) Underthrust of Tarim under the Tien Shan and Deep Structure of their Junction Zone: Main Results of Seismic Studies on the MANAS Profile (Kashgar-Song-köl). Geotectonics, 44, 102-126. http://dx.doi.org/10.1134/S0016852110020020

[89] Vinnik, L.P., Aleshin, I.M., Kaban, M.K., Kiselev, S.G., Kosarev, G.L., Oreshin, S.I. and Reigber, C. (2006) Crust and Mantle of the Tien Shan from Data of Receiver Function Tomography. Physics of the Earth, 42, 639-651. http://dx.doi.org/10.1134/S1069351306080027

[90] Artyushkov, E.V. (2012) Neotectonic Crustal Uplifts as a Consequence of Mantle Fluid Infiltration into the Lithosphere. Russian Geology and Geophysics, 53, 738-760. http://dx.doi.org/10.1016/j.rgg.2012.04.005

[91] Milanovsky, E.E., Rastsvetaev, L.M. and Kuhmazov, S.U. (1989) Modern Geodynamics of the Elbrus-Caucasus Mineral Waters Region of the North Caucasus. In: Geodynamics of Caucasus, Nauka, Moscow, 99-105. (in Russian)

[92] Laverov, N.P. (Ed.) (2005) Modern and Holocene Volcanism in Russia. Nauka, Moscow, 604 p. (in Russian)

[93] Ershov, A.V. and Nikishin, A.M. (2004) Recent Geodynamics of the Caucasus-Arabia-East Africa Region. Geotectonics, 38, 123-136. 